\title{
Mosquito Distribution in Northwestern Russia: Species of the Genera Anopheles Meigen, Coquillettidia Dyar, Culex L., and Culiseta Felt (Diptera, Culicidae)
}

\author{
A. V. Khalin ${ }^{a *}$, S. V. Aibulatov ${ }^{a}$, and I. V. Filonenko ${ }^{b}$ \\ ${ }^{a}$ Zoological Institute, Russian Academy of Sciences, St. Petersburg, 199034 Russia \\ ${ }^{b}$ Vologda Branch of the Russian Federal Research Institute \\ of Fisheries and Oceanography, Vologda, 160012 Russia \\ *e-mail: hallisimo@yandex.ru
}

Received November 17, 2020; revised February 6, 2021; accepted February 6, 2021

\begin{abstract}
Records of 16 species of the mosquito genera Anopheles, Coquillettidia, Culex, and Culiseta (Diptera: Culicidae) in Northwestern Russia are mapped. The values of the sum of active temperatures above $0^{\circ} \mathrm{C}$ were shown to correlate with the position of the northern range boundaries of mosquito species, according to which 16 species were included in 4 distribution groups.
\end{abstract}

Keywords: mosquitoes, distribution, Northwestern Russia, sum of active temperatures above $0^{\circ} \mathrm{C}$, Diptera, Culicidae, Anopheles, Coquillettidia, Culex, Culiseta

DOI: $10.1134 / \mathrm{S} 0013873821030040$

Mosquitoes (Diptera: Culicidae) are widespread over the whole Northwestern Region of Russia' ${ }^{1}$ (NWR, Fig. 1). Females of some mosquito species bite humans and are responsible for the transmission of medically important pathogens and parasites such as viruses, bacteria, protozoans, and nematodes. For example, Sindbis, Batai, and California encephalitis viruses are known to be transmitted in NWR by mosquitoes of the genera Aedes $^{2}$ Meigen, 1818, Anopheles Meigen, 1818, and Culex Linnaeus, 1758 (Lvov et al., 1989; Alkhovsky, 2016). A study of the associations between mosquitoes and specific pathogens requires both correct identifica-

\footnotetext{
1 The Northwestern Region of Russia in our interpretation corresponds to the Northwestern Federal District of Russia, which includes Murmansk (MP), Arkhangelsk (AP), Leningrad (LP), Vologda (VP), Kaliningrad (KP), Pskov (PP), Novgorod provinces (NP), and the republics of Karelia (RK) and Komi. The Nenets Autonomous Okrug (NAO) is considered here separately from the rest of Arkhangelsk Province.

2 We use the classification by Wilkerson and co-authors (Wilkerson et al., 2015), according to which the genus Aedes includes the subgenus Ochlerotatus Lynch Arribalzaga, 1891.
}

tion of the vector species and reliable data on the mosquito fauna in the study region.

In this article we continue the study of bloodsucking insects in NWR, which has been carried out at the Zoological Institute of the Russian Academy of Sciences (ZIN) since 2005. First, we made a general outline of the regional faunas of mosquitoes, blackflies (Simuliidae), horseflies (Tabanidae), and biting midges (Ceratopogonidae) (Medvedev et al., 2007); then mosquito distribution was considered in greater detail (Aibulatov and Khalin, 2019; Aibulatov et al., 2020; Khalin and Aibulatov, 2020, 2021).

During further analysis of the northern range boundaries we have mapped the records of 16 mosquito species of the genera Anopheles, Coquillettidia Dyar, 1905, Culex, and Culiseta Felt, 1904 in the whole territory of NWR. In this article we examine all the species of Culicidae present in the NWR fauna, with the exception of Aedes species. We use our earlier data (Khalin and Aibulatov, 2020), e.g., the results of identification of the material collected by S.V. Aibulatov and A.V. Khalin 


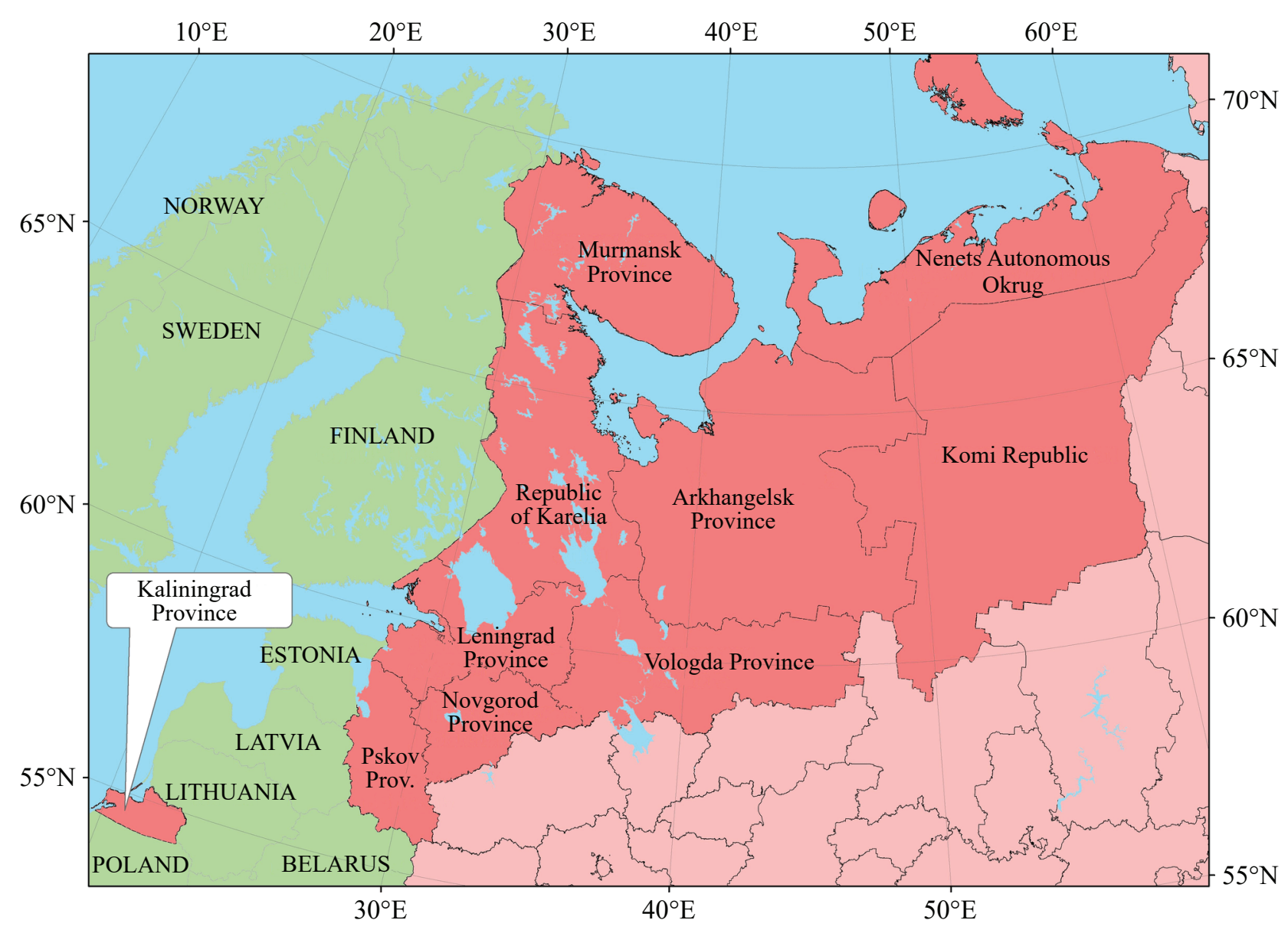

Fig. 1. The Northwestern Region of Russia.

and revision of the ZIN collection. In addition, it includes analysis of additional literature for some regions of NWR.

The distribution within NWR has been described for the following species: Anopheles atroparvus van Thiel, 1927, A. beklemishevi Stegnii et Kabanova, 1976, A. claviger (Meigen, 1804), A. maculipennis Meigen, 1818, A. messeae Falleroni, 1926, Culex modestus Ficalbi, 1890, C. pipiens Linnaeus, 1758, C. torrentium Martini, 1925, C. territans Walker, 1856, Culiseta fumipennis (Stephens, 1825), C. morsitans (Theobald, 1901), C. ochroptera (Peus, 1935), C. alaskaensis (Ludlow, 1906), C. annulata (Schrank, 1776), C. bergrothi (Edwards, 1921), and Coquillettidia richiardii (Ficalbi, 1889).

The coordinates of the collection localities of each species were entered in a *.shp file and analyzed using an ArcGIS 10 software. In addition, the file included data on the source of information: our collections, ZIN collection, and literature data. The geographic information system (GIS) is useful for analysis of the records of bloodsucking insect species and description of their geographic distribution. For instance, the mapped species records can be combined with various thematic maps (e.g., climatic ones), containing the original parameters in the given points of the territory or interpolated results based on analysis of the distribution of factors. In this way, the known collection localities of a given species can be used to extrapolate its range boundaries in the region.

Mosquitoes are poikilothermic animals whose metabolism and phenology directly depend on the environmental conditions; therefore, they can exist only within a certain range of environmental factors. In the article, the records of mosquito species were related to a climatic parameter, the sum of active temperatures above 
$0^{\circ} \mathrm{C}(\mathrm{SAT})^{3}$. The benefis of using SAT in the study of mosquito distribution had been noted earlier (e.g., Yasyukevich et al., 2017, 2019). Various climatic parameters are considered when predicting the changes in the distribution of agents of transmissible diseases and of their vectors (Pavlovsky, 1964; Korenberg, 1975). In medical entomology and practical epidemiology, thermal parameters are used to control malaria and other diseases in a given territory (Beklemishev et al., 1949; Moshkovsky and Rashina, 1951). The pest control measures in agriculture is determined by the thermal parameters of insect pest development (Popova and Popov, 2013).

In this research we used the free data on the main climatic factors available at the AgroAtlas web site (Afonin et al., 2008) in order to characterize the mosquito distribution in NWR in relation to the environmental parameters. The records of mosquito species close to the northern boundaries of their ranges were compared with the SAT values of the corresponding territories, and the results were used to extrapolate the northern distribution boundaries of 16 species of Culicidae within NWR. We used the SAT values for areas of $100 \mathrm{~km}^{2}$, obtained from the AgroAtlas web site (Afonin et al., 2008). The SAT values were color coded from green to red (see map legend in Fig. 2).

Below, the records of 16 mosquito species are plotted on the map of NWR with SAT values. The source of information is indicated for each species: our collections, the ZIN material or literature data.

The northernmost records of mosquito species within NWR, including the exact collection localities and their coordinates, were considered in our earlier paper (Khalin and Aibulatov, 2021). The records of mosquitoes from the territories with the minimal SAT values are listed in Table 1. The number of such records given for each species reflects the current level of knowledge of its distribution. A single locality corresponding to the territory with the lowest SAT value is given in some cases: Anopheles atroparvus, Culiseta fumipennis, and C. annulata. For most species, two localities are given, in the western and the eastern parts of NWR. For example, such localities for Anopheles beklemishevi are RK in the

\footnotetext{
3 The SAT is the sum of mean daily air temperatures exceeding $0^{\circ} \mathrm{C}$ for one year.
}

west and Komi in the east of NWR. For the species whose distribution is somewhat better known, three localities are listed in order to describe the northern range boundary more correctly; for example, the localities of Anopheles claviger are SPb (western part), VP (central part), and Komi (eastern part). Some records of species are considered by us to be doubtful; they are marked with asterisks $(*)$ and discussed in the corresponding Note sections.

Maps of NWR showing the collection localities of the 16 mosquito species are given below. For each species, the examined material (our collections and the ZIN collection) is listed when present, its distribution in NWR and adjacent territories is characterized, and references to the sources of data are provided. In addition, the distribution of each species outside NWR is briefly described based on the literature data (Gutsevich et al., 1970; Khalin and Gornostaeva, 2008; Becker et al., 2010). The records for Belarus are based on the data of Suslo (2019); those in Europe 4 are based on the data of Robert and co-authors (Robert et al., 2019). The distribution of Culiseta species in Russia outside NWR is based on the data of Maslov (1967).

\section{RECORDS OF MOSQUITO SPECIES IN NORTHWESTERN RUSSIA}

\section{Anopheles (Anopheles) atroparvus van Thiel, 1927}

Distribution. KP (Levenson et al., 1959) (Fig. 2).

Sweden (Dahl, 1977; Lundström et al., 2013). Latvia (Spungis, 2000). Lithuania (Pakalniskis et al., 2006).

South of European Russia. Europe (ranging northward to the UK, Belgium, and Denmark); Belarus, Ukraine, Moldova.

\section{Anopheles (Anopheles) beklemishevi Stegnii et Kabanova, 1976}

Distribution (Fig. 2). RK (Stegnii et al., 1978; Perevozkin et al., 2012). LP (Stegnii et al., 1978; Moskaev

\footnotetext{
${ }^{4}$ In the Distribution section for each species, we consider under "Europe" the continental and insular parts of Europe outside Russia, excluding Norway, Sweden, Finland, and the former USSR countries.
}

ENTOMOLOGICAL REVIEW Vol. 101 No. 32021 


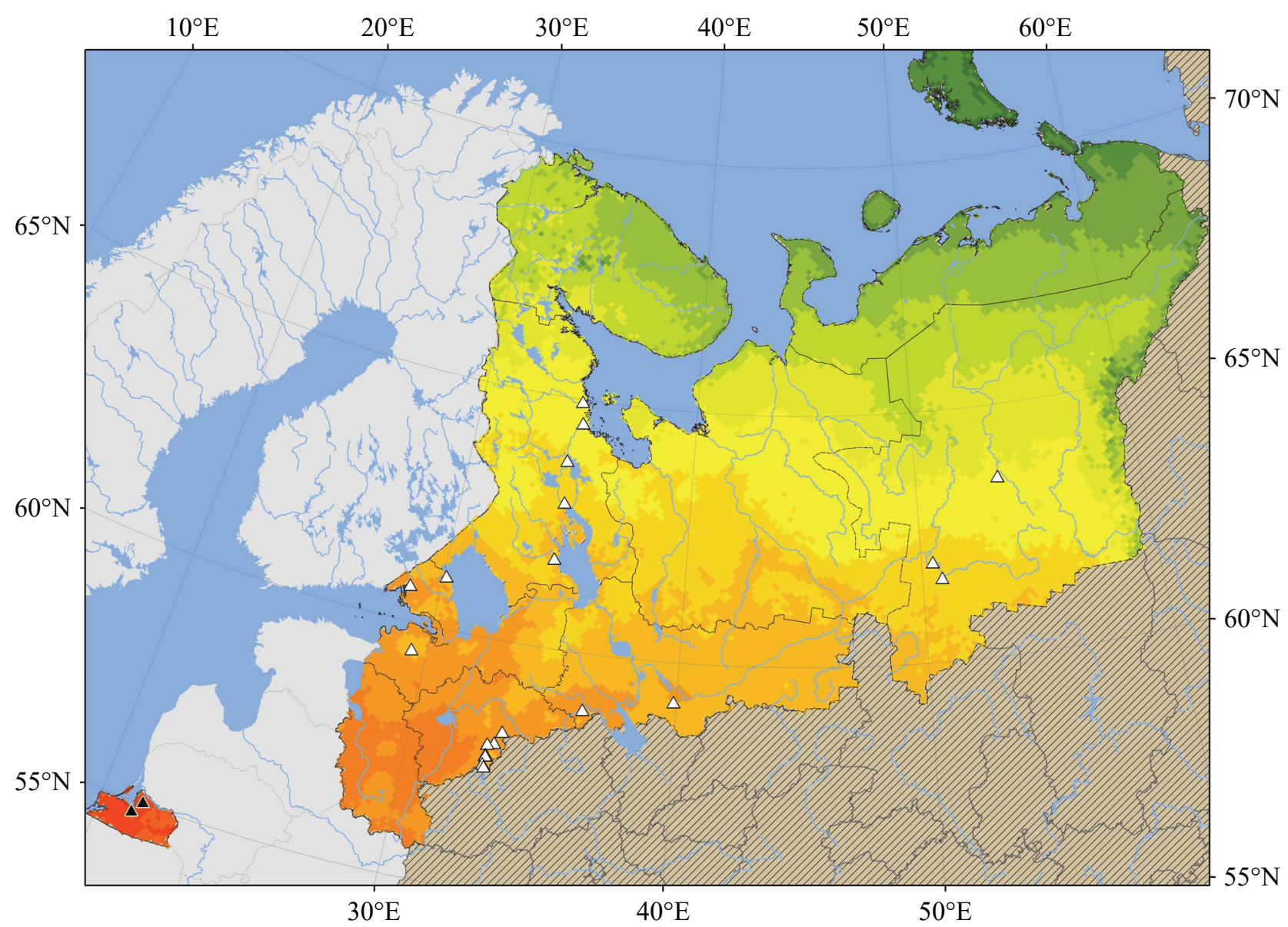

Sum of active temperatures above $0^{\circ} \mathrm{C}$

$\begin{array}{lllllllllllllll}80 & 300 & 500 & 700 & 900 & 1100 & 1300 & 1500 & 1700 & 1900 & 2100 & 2300 & 2500 & 2700 & 2900\end{array}$

Fig. 2. Collection localities of Anopheles atroparvus van Thiel (black triangles) and A. beklemishevi Stegnii et Kabanova (white triangles) in Northwestern Russia, according to the literature data. The territories with different values of the sum of active temperatures above $0^{\circ} \mathrm{C}$ are color coded (see legend).

et al., 2016). VP (Belova et al., 2008). Komi (Panyukova and Ostroushko, 2017). NP (Moskaev et al., 2015).

Sweden (Lundström et al., 2013). Finland (Culverwell et al., 2021).

European Russia, Siberia. Sweden, Finland.

\section{Anopheles (Anopheles) claviger}

(Meigen, 1804)

Material. SPb, LP, VP (Fig. 3).

Distribution. SPb (Fedorov, 1969). Komi (Panyukova and Ostroushko, 2017). KP (Levenson et al., 1959).
PP (Pavlovsky, 1935; Medvedev and Matov, 1999). NP (Medvedev and Panyukova, 2005).

Norway (Mehl, 1996). Sweden (Dahl, 1975; Schäfer and Lundström, 2001; Lundström et al., 2013; Möhlmann et al., 2017). Finland (Utrio, 1977; Culverwell, 2018; Culverwell et al., 2021). Estonia (Remm, 1957). Latvia (Spungis, 2000). Lithuania (Pakalniskis et al., 2006).

European Russia, West Siberia. Europe (ranging northward to the UK, Belgium, and Denmark); North Africa, Belarus, Ukraine, Moldova, Transcaucasia, West and Middle Asia. 
Table 1. Records of mosquitoes in Northwestern Russia corresponding to the territories with the lowest values of the sums of active temperatures (SAT) above $0^{\circ} \mathrm{C}$

\begin{tabular}{|c|c|c|c|c|c|}
\hline Species & $\begin{array}{c}\text { Province / republic, } \\
\text { district }\end{array}$ & Collection locality & Coordinates & $\mathrm{SAT},{ }^{\circ} \mathrm{C}$ & Source of data \\
\hline $\begin{array}{l}\text { Anopheles } \\
\text { atroparvus }\end{array}$ & KP, Slavskii & - & $\begin{array}{l}54^{\circ} 03^{\prime} 00.0^{\prime \prime} \mathrm{N} \\
21^{\circ} 40^{\prime} 00.0^{\prime \prime} \mathrm{E}\end{array}$ & 2721.8 & Levenson et al., 1959 \\
\hline \multirow[t]{2}{*}{ A. beklemishevi } & RK, Belomorskii & Belomorsk & $\begin{array}{l}64^{\circ} 31^{\prime} 49.15^{\prime \prime} \mathrm{N} \\
34^{\circ} 45^{\prime} 47.98^{\prime \prime} \mathrm{E}\end{array}$ & 1599.5 & Perevozkin et al., 2012 \\
\hline & Komi, Ukhta & Ukhta & $\begin{array}{c}63^{\circ} 33^{\prime} 45.45^{\prime \prime} \mathrm{N} \\
53^{\circ} 41^{\prime} 2.48^{\prime \prime} \mathrm{E}\end{array}$ & 1577.2 & $\begin{array}{l}\text { Panyukova and } \\
\text { Ostroushko, } 2017\end{array}$ \\
\hline \multirow[t]{2}{*}{ A. claviger } & VP, Totemskii & Totma & $\begin{array}{l}59^{\circ} 58^{\prime} 24.55^{\prime \prime} \mathrm{N} \\
42^{\circ} 45^{\prime} 31.94^{\prime \prime} \mathrm{E}\end{array}$ & 1989.6 & Authors' collections \\
\hline & Komi, Syktyvkar & Syktyvkar & $\begin{array}{l}61^{\circ} 40^{\prime} 7.65^{\prime \prime} \mathrm{N} \\
50^{\circ} 50^{\prime} 11.04^{\prime \prime} \mathrm{E}\end{array}$ & 1863.6 & $\begin{array}{l}\text { Panyukova and } \\
\text { Ostroushko, } 2017\end{array}$ \\
\hline \multirow[t]{2}{*}{ A. maculipennis } & RK, Kemskii & Kem & $\begin{array}{l}64^{\circ} 57^{\prime} 19.92^{\prime \prime} \mathrm{N} \\
34^{\circ} 35^{\prime} 54.14^{\prime \prime} \mathrm{E}\end{array}$ & 1607.3 & Perevozkin et al., 2012 \\
\hline & Komi, Ukhta & Ukhta & $\begin{array}{c}63^{\circ} 33^{\prime} 45.45^{\prime \prime} \mathrm{N} \\
53^{\circ} 41^{\prime} 2.48^{\prime \prime} \mathrm{E}\end{array}$ & 1577.2 & $\begin{array}{l}\text { Gordeev and Moskaev, } \\
2014\end{array}$ \\
\hline \multirow[t]{3}{*}{ A. messeae } & MP, Pechengskii & Shuioniioki River & $\begin{array}{l}69^{\circ} 16^{\prime} 2.06^{\prime \prime} \mathrm{N} \\
30^{\circ} 8^{\prime} 24.28^{\prime \prime} \mathrm{E}\end{array}$ & 1136.4 & ZIN collection* \\
\hline & AP, Arkhangelsk & Arkhangelsk & $\begin{array}{l}64^{\circ} 32^{\prime} 23.68^{\prime \prime} \mathrm{N} \\
40^{\circ} 30^{\prime} 56.71^{\prime \prime} \mathrm{E}\end{array}$ & 1659.7 & Sharkov, 1982 \\
\hline & Komi, Ukhta & Ukhta & $\begin{array}{c}63^{\circ} 33^{\prime} 45.45^{\prime \prime} \mathrm{N} \\
53^{\circ} 41^{\prime} 2.48^{\prime \prime} \mathrm{E}\end{array}$ & 1577.2 & $\begin{array}{l}\text { Panyukova and } \\
\text { Ostroushko, } 2017\end{array}$ \\
\hline \multirow[t]{3}{*}{ Culex modestus } & NP, Khvoininskii & Khvoinaya & $\begin{array}{l}58^{\circ} 54^{\prime} 00.0^{\prime \prime} \mathrm{N} \\
34^{\circ} 30^{\prime} 00.0^{\prime \prime} \mathrm{E}\end{array}$ & 2112.3 & $\begin{array}{l}\text { Panyukova and } \\
\text { Medvedev, } 2008\end{array}$ \\
\hline & VP, Vologodskii & - & $\begin{array}{l}59^{\circ} 13^{\prime} 13.79^{\prime \prime} \mathrm{N} \\
39^{\circ} 53^{\prime} 29.48^{\prime \prime} \mathrm{E}\end{array}$ & 2124.0 & Belova et al., 2008 \\
\hline & LP, Vsevolozhskii & Novosaratovka & $\begin{array}{l}59^{\circ} 50^{\prime} 29.5^{\prime \prime} \mathrm{N} \\
30^{\circ} 31^{\prime} 32.57^{\prime \prime} \mathrm{E}\end{array}$ & 2185.7 & ZIN collection \\
\hline \multirow[t]{4}{*}{ C.pipiens } & AP, Novaya Zemlya & Belushya Bay & $\begin{array}{c}71^{\circ} 30^{\prime} 38.91^{\prime \prime} \mathrm{N} \\
52^{\circ} 18^{\prime} 3^{\prime \prime} \mathrm{E}\end{array}$ & 519.2 & Sack, 1923* \\
\hline & NAO, Zapolyarnyi & Vaygach Island & $\begin{array}{l}70^{\circ} 2^{\prime} 10.73^{\prime \prime} \mathrm{N} \\
59^{\circ} 28^{\prime} 55.59^{\prime \prime} \mathrm{E}\end{array}$ & 558.7 & de Meijere, $1910^{*}$ \\
\hline & MP, Kirovskii & Lake Vudyavr basin & $\begin{array}{l}67^{\circ} 37^{\prime} 50.5^{\prime \prime} \mathrm{N} \\
33^{\circ} 40^{\prime} 15.2^{\prime \prime} \mathrm{E}\end{array}$ & 848.3 & ZIN collection \\
\hline & Komi, Vorkuta & Vorkuta & $\begin{array}{c}67^{\circ} 29^{\prime} 50.68^{\prime \prime} \mathrm{N} \\
64^{\circ} 3^{\prime} 39.93^{\prime \prime} \mathrm{E}\end{array}$ & 879.0 & $\begin{array}{l}\text { Panyukova and } \\
\text { Ostroushko, } 2017\end{array}$ \\
\hline \multirow[t]{2}{*}{ C. torrentium } & RK, Kondopozhskii & Kivach & $\begin{array}{l}62^{\circ} 16^{\prime} 33.04^{\prime \prime} \mathrm{N} \\
33^{\circ} 58^{\prime} 54.59^{\prime \prime} \mathrm{E}\end{array}$ & 1923.3 & Polevoi, 2006 \\
\hline & $\begin{array}{l}\text { Komi, Troitsko- } \\
\text { Pechorskii }\end{array}$ & Yaksha & $\begin{array}{c}61^{\circ} 49^{\prime} 29.68^{\prime \prime} \mathrm{N} \\
56^{\circ} 49^{\prime} 15.96^{\prime \prime} \mathrm{E}\end{array}$ & 1733.0 & Panyukova, 2019 \\
\hline \multirow[t]{2}{*}{ C. territans } & Komi, Udorskii & Mezhdurechensk & $\begin{array}{l}63^{\circ} 15^{\prime} 00.0^{\prime \prime} \mathrm{N} \\
48^{\circ} 33^{\prime} 00.0^{\prime \prime} \mathrm{E}\end{array}$ & 1587.1 & $\begin{array}{l}\text { Panyukova and } \\
\text { Ostroushko, } 2017\end{array}$ \\
\hline & RK, Pryazhinskii & Pryakka & $\begin{array}{l}61^{\circ} 41^{\prime} 33.0^{\prime \prime} \mathrm{N} \\
33^{\circ} 37^{\prime} 12.0^{\prime \prime} \mathrm{E}\end{array}$ & 1874.1 & ZIN collection \\
\hline
\end{tabular}


Table 1. (Contd.)

\begin{tabular}{|c|c|c|c|c|c|}
\hline Species & $\begin{array}{c}\text { Province / republic, } \\
\text { district }\end{array}$ & Collection locality & Coordinates & $\mathrm{SAT},{ }^{\circ} \mathrm{C}$ & Source of data \\
\hline Culiseta fumipennis & RK, Medvezhegorskii & Medvezhegorsk & $\begin{array}{l}62^{\circ} 18^{\prime} 26.91^{\prime \prime} \mathrm{N} \\
35^{\circ} 17^{\prime} 29.44^{\prime \prime} \mathrm{E}\end{array}$ & 1951.0 & Jakovlev et al., 2014 \\
\hline \multirow[t]{2}{*}{ C. morsitans } & MP, Kandalakshskii & Kandalaksha & $\begin{array}{c}67^{\circ} 9^{\prime} 4.51^{\prime \prime} \mathrm{N} \\
32^{\circ} 24^{\prime} 46.16^{\prime \prime} \mathrm{E}\end{array}$ & 1227.8 & ZIN collection \\
\hline & Komi, Vyktul & Ust-Shchugel & $\begin{array}{l}64^{\circ} 16^{\prime} 1.87^{\prime \prime} \mathrm{N} \\
57^{\circ} 37^{\prime} 6.86^{\prime \prime} \mathrm{E}\end{array}$ & 1454.1 & $\begin{array}{l}\text { Panyukova and } \\
\text { Ostroushko, } 2017\end{array}$ \\
\hline \multirow[t]{2}{*}{ C. ochroptera } & Komi, Sosnogorskii & Nizhnii Odes & $\begin{array}{l}63^{\circ} 38^{\prime} 20.12^{\prime \prime} \mathrm{N} \\
54^{\circ} 50^{\prime} 45.02^{\prime \prime} \mathrm{E}\end{array}$ & 1490.6 & $\begin{array}{l}\text { Panyukova and } \\
\text { Ostroushko, } 2017\end{array}$ \\
\hline & RK, Pryazhinskii & Pryakka & $\begin{array}{l}61^{\circ} 41^{\prime} 33.0^{\prime \prime} \mathrm{N} \\
33^{\circ} 37^{\prime} 12.0^{\prime \prime} \mathrm{E}\end{array}$ & 1874.1 & ZIN collection \\
\hline \multirow[t]{2}{*}{ C. alaskaensis } & Komi, Vorkuta & Polar Urals & $\begin{array}{c}67^{\circ} 0^{\prime} 44.035^{\prime \prime} \mathrm{N} \\
65^{\circ} 5^{\prime} 45.614^{\prime \prime} \mathrm{E}\end{array}$ & 775.5 & $\begin{array}{l}\text { Beltyukova and } \\
\text { Mitrofanova, } 1971\end{array}$ \\
\hline & MP, Kirovskii & Lake Vudyavr basin & $\begin{array}{l}67^{\circ} 37^{\prime} 50.5^{\prime \prime} \mathrm{N} \\
33^{\circ} 40^{\prime} 15.2^{\prime \prime} \mathrm{E}\end{array}$ & 848.3 & ZIN collection \\
\hline C. annulata & LP, Kingiseppskii & Kurgolovo & $\begin{array}{l}59^{\circ} 46^{\prime} 19.3^{\prime \prime} \mathrm{N} \\
28^{\circ} 07^{\prime} 49.1^{\prime \prime} \mathrm{E}\end{array}$ & 2226.4 & Authors' collections \\
\hline \multirow[t]{2}{*}{ C. bergrothi } & MP, Kirovskii & Lake Vudyavr basin & $\begin{array}{l}67^{\circ} 37^{\prime} 50.5^{\prime \prime} \mathrm{N} \\
33^{\circ} 40^{\prime} 15.2^{\prime \prime} \mathrm{E}\end{array}$ & 848.3 & ZIN collection \\
\hline & Komi, Vorkuta & Vorkuta & $\begin{array}{c}67^{\circ} 29^{\prime} 50.68^{\prime \prime} \mathrm{N} \\
64^{\circ} 3^{\prime} 39.93^{\prime \prime} \mathrm{E}\end{array}$ & 879.0 & $\begin{array}{l}\text { Panyukova and } \\
\text { Ostroushko, } 2017\end{array}$ \\
\hline \multirow[t]{2}{*}{$\begin{array}{l}\text { Coquillettidia } \\
\text { richiardii }\end{array}$} & RK, Prionezhskii & Pukhta & $\begin{array}{l}61^{\circ} 29^{\prime} 55.0^{\prime \prime} \mathrm{N} \\
34^{\circ} 39^{\prime} 35.0^{\prime \prime} \mathrm{E}\end{array}$ & 1966.7 & Lobkova, 1956 \\
\hline & Komi, Priluzskii & Prislon & $\begin{array}{c}59^{\circ} 36^{\prime} 30.0^{\prime \prime} \mathrm{N} \\
49^{\circ} 25^{\prime} 20.0^{\prime \prime} \mathrm{E}\end{array}$ & 2021.6 & $\begin{array}{l}\text { Panyukova and } \\
\text { Ostroushko, } 2017\end{array}$ \\
\hline
\end{tabular}

Dash indicates that the exact locality was not specified in the literature; in such cases the coordinates of the district center are given.

\section{Anopheles (Anopheles) maculipennis Meigen, 1818 sensu stricto ${ }^{5}$}

Distribution (Fig. 4). RK (Perevozkin et al., 2012; Jakovlev et al., 2014). LP (Stegnii et al., 1978; Moskaev et al., 2016). Komi (Gordeev and Moskaev, 2014; Panyukova and Ostroushko, 2017). NP (Moskaev et al., 2015). KP (Levenson et al., 1959; Bernotiene, 2012; Perevozkin et al., 2018).

5 Anopheles maculipennis is considered here as a single species and not as a species complex. Identification of species in this complex requires special techniques, whereas A. maculipennis sensu lato can be diagnosed by distinct larval and adult morphological characters. Correspondingly, here we give references only to those publications in which the material was identified not to A. maculipennis $\mathrm{s}$. 1. but to individual species.
Sweden (Dahl, 1977; Lundström et al., 2013; Möhlmann et al., 2017). Finland (Utrio, 1977; Culverwell, 2018; Culverwell et al., 2021). Latvia (Spungis, 2000). Lithuania (Pakalniskis et al., 2006).

European Russia, West Siberia. Europe (ranging northward to the UK, Belgium, and Denmark); North Africa, Belarus, Ukraine, Moldova, Transcaucasia, West and Middle Asia.

\section{Anopheles (Anopheles) messeae Falleroni, 1926}

Material. MP* (Fig. 5).

Distribution. AP (Sharkov, 1982). RK (Lobkova, 1956; Stegnii et al., 1978; Perevozkin et al., 2012). SPb (Fedorov, 1969; Stegnii et al., 1978). LP (Stegnii et al., 


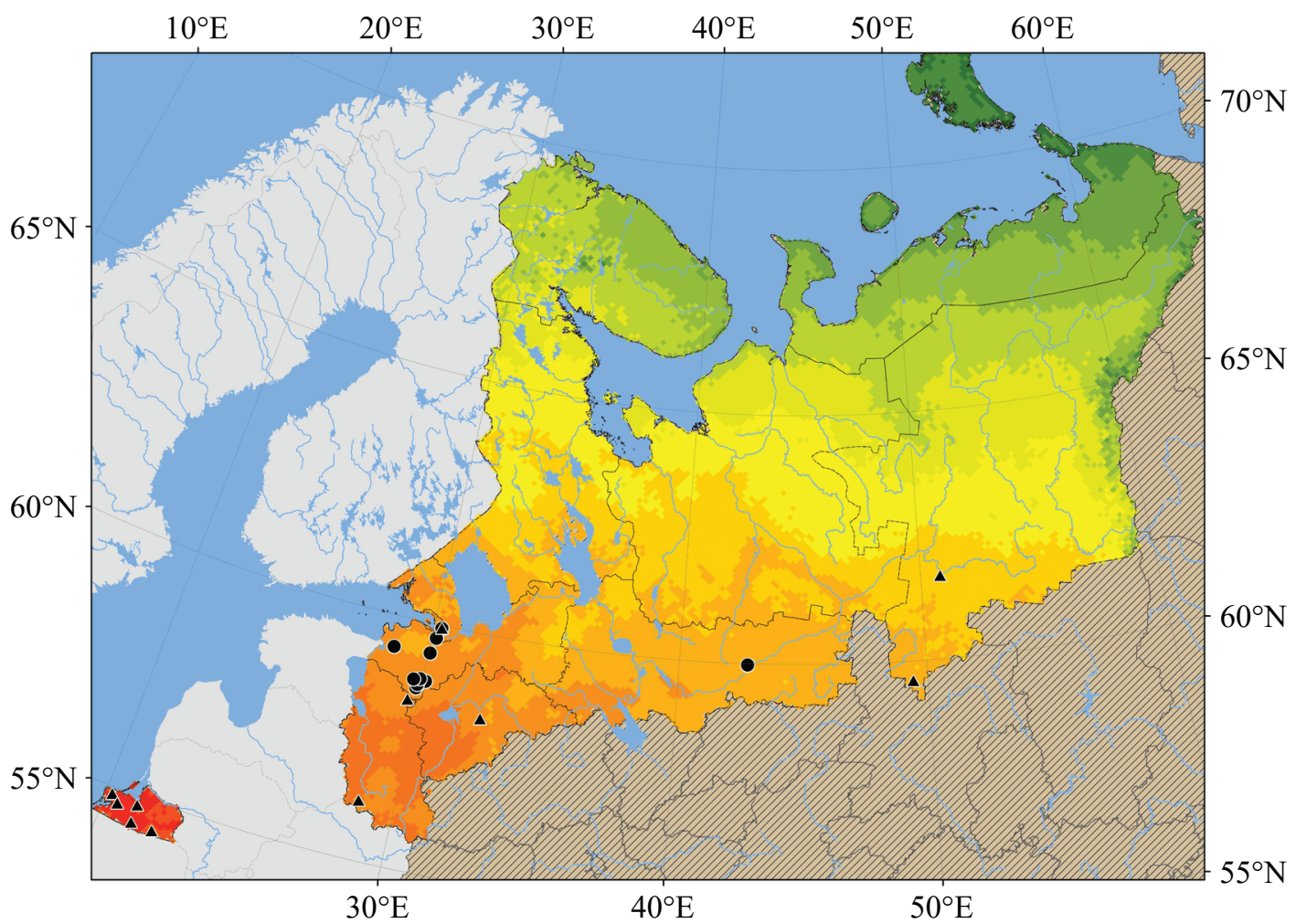

Fig. 3. Collection localities of Anopheles claviger (Meigen) in Northwestern Russia, according to the collection material (circles) and the literature data (triangles).

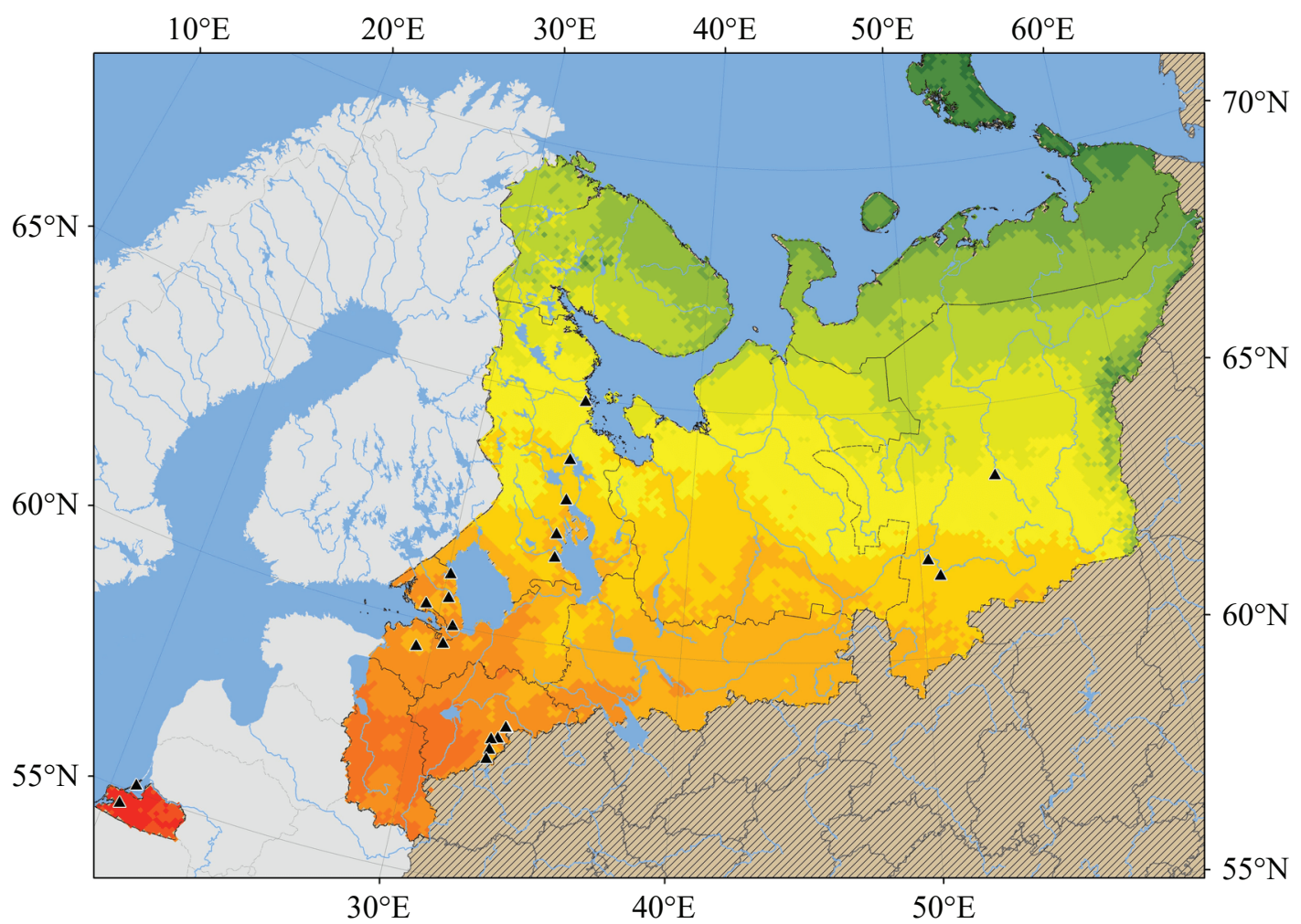

Fig. 4. Collection localities of Anopheles maculipennis Meigen in Northwestern Russia. Designations as in Fig. 3. 
1978; Moskaev et al., 2016). VP (Sharkov, 1982; Belova et al., 2008). Komi (Ostroushko, 1986; Panyukova and Ostroushko, 2017). PP (Chetverikova, 2014). NP (Moskaev et al., 2015). KP (Levenson et al., 1959; Perevozkin et al., 2018).

Norway (Mehl, 1996). Sweden (Dahl, 1977; Lundström et al., 2013). Finland (Utrio, 1977; Culverwell, 2018; Culverwell et al., 2021). Latvia (Spungis, 2000). Lithuania (Pakalniskis et al., 2006).

European Russia, Siberia. Europe (ranging northward to the UK, Belgium, and Denmark); Belarus, Ukraine, Moldova, Middle Asia, Northeast China.

Note. The only specimen studied by us is a head preparation of a female mosquito identified earlier by A.V. Gutsevich. We cannot confirm this identification. It is possible that the female was reared from an egg identified as Anopheles messeae.

\section{Culex (Barraudius) modestus}

Ficalbi, 1890

Material. SPb, LP (Fig. 6).

Distribution. VP (Belova et al., 2008). PP (Medvedev and Matov, 1999). NP (Panyukova and Medvedev, 2008).

Sweden (Möhlmann et al., 2017).

European Russia, Siberia, the Russian Far East. Europe (ranging northward to the UK, the Netherlands, and Denmark); North Africa, Belarus, Ukraine, Moldova, Transcaucasia, West, Middle, and South Asia.

\section{Culex (Culex) pipiens Linnaeus, 1758}

Material. MP, RK, SPb, LP, KP, PP, NP (Fig. 7).

Distribution. MP (Shub and Nikolaev, 1937; Lobkova, 1964; Tamarina and Aleksandrova, 1974; Sharkov, 1976). AP* (Sack, 1923). NAO* (de Meijere, 1910). RK (Shingareva, 1926; Shub and Nikolaev, 1937; Lobkova, 1956, 1980; Lobkova and Makarova, 1961; Sharkov et al., 1984; Polevoi, 2006). SPb (Osten-Sacken, 1858; Fedorov, 1946, 1969; Gutsevich, 1948). VP (Adrianov, 1953; Ozerov, 1957; Sharkov, 1982; Belova et al., 2008). Komi (Shub and Nikolaev, 1937; Ostroushko, 1986; Panyukova and Ostroushko, 2017). KP (Levenson et al., 1959; Bernotiene, 2012). PP (Medvedev and Matov, 1999; Chetverikova, 2014). NP (Fedorova, 1977; Kunkova, 2000; Panyukova and Medvedev, 2008).

Norway (Natvig, 1948; Mehl, 1996). Sweden (Natvig, 1948; Dahl, 1975; Schäfer and Lundström, 2001; Lundström et al., 2013; Hesson et al., 2015; Möhlmann et al., 2017). Finland (Natvig, 1948; Utrio, 1977; Culverwell, 2018; Culverwell et al., 2021). Estonia (Remm, 1957). Latvia (Spungis, 2000). Lithuania (Pakalniskis et al., 2006).

European Russia, Siberia, the Russian Far East. Europe (ranging northward to the UK, Belgium, and Denmark); North Africa, Belarus, Ukraine, Moldova, West and Middle Asia. Holarctic (excluding most transpolar regions), locally in the Ethiopian, Neotropical, and Australian regions.

Note. The records of Culex pipiens from AP [the Novaya Zemlya Archipelago, Belushya Bay (Sack, 1923)] and NAO [Zapolyarnyi District, Vaygach Island (de Meijere, 1910)] were probably based on misidentification. The other records are located far southward from the Novaya Zemlya and Vaygach Island (Table 1; Fig. 7), including those outside Russia, in Sweden: Norrbotten, $67^{\circ} 08^{\prime} 09.0^{\prime \prime} \mathrm{N}, 18^{\circ} 30^{\prime} 03.5^{\prime \prime} \mathrm{E}$ (Lundström et al.,

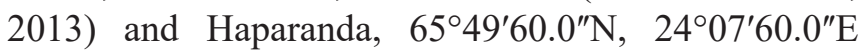
(Hesson et al., 2015); in Finland: Lahti, 60 $58^{\prime} 60.0^{\prime \prime} \mathrm{N}$, $25^{\circ} 39^{\prime} 20.0^{\prime \prime} \mathrm{E}$ (Hesson et al., 2015) and Larsmo, 63 ${ }^{\circ} 45^{\prime} \mathrm{N}$, $22^{\circ} 48^{\prime} \mathrm{E}$ (Natvig, 1948).

\section{Culex (Culex) torrentium Martini, 1925}

Material. SPb, LP, NP (Fig. 8).

Distribution. RK (Polevoi, 2006). SPb (Fedorov, 1969). VP (Belova et al., 2008). Komi (Panyukova, 2019). PP (Chetverikova, 2014). NP (Kunkova and Fedorova, 2003; Panyukova and Medvedev, 2008).

Norway (Mehl, 1996). Sweden (Schäfer and Lundström, 2001; Lundström et al., 2013; Hesson et al., 2015). Finland (Utrio, 1977; Culverwell, 2018; Culverwell et al., 2021). Estonia (Remm, 1957). Lithuania (Pakalniskis et al., 2006).

European Russia, West Siberia. Europe (ranging northward to the UK, Belgium, and Denmark); Belarus, Moldova, West Asia. 


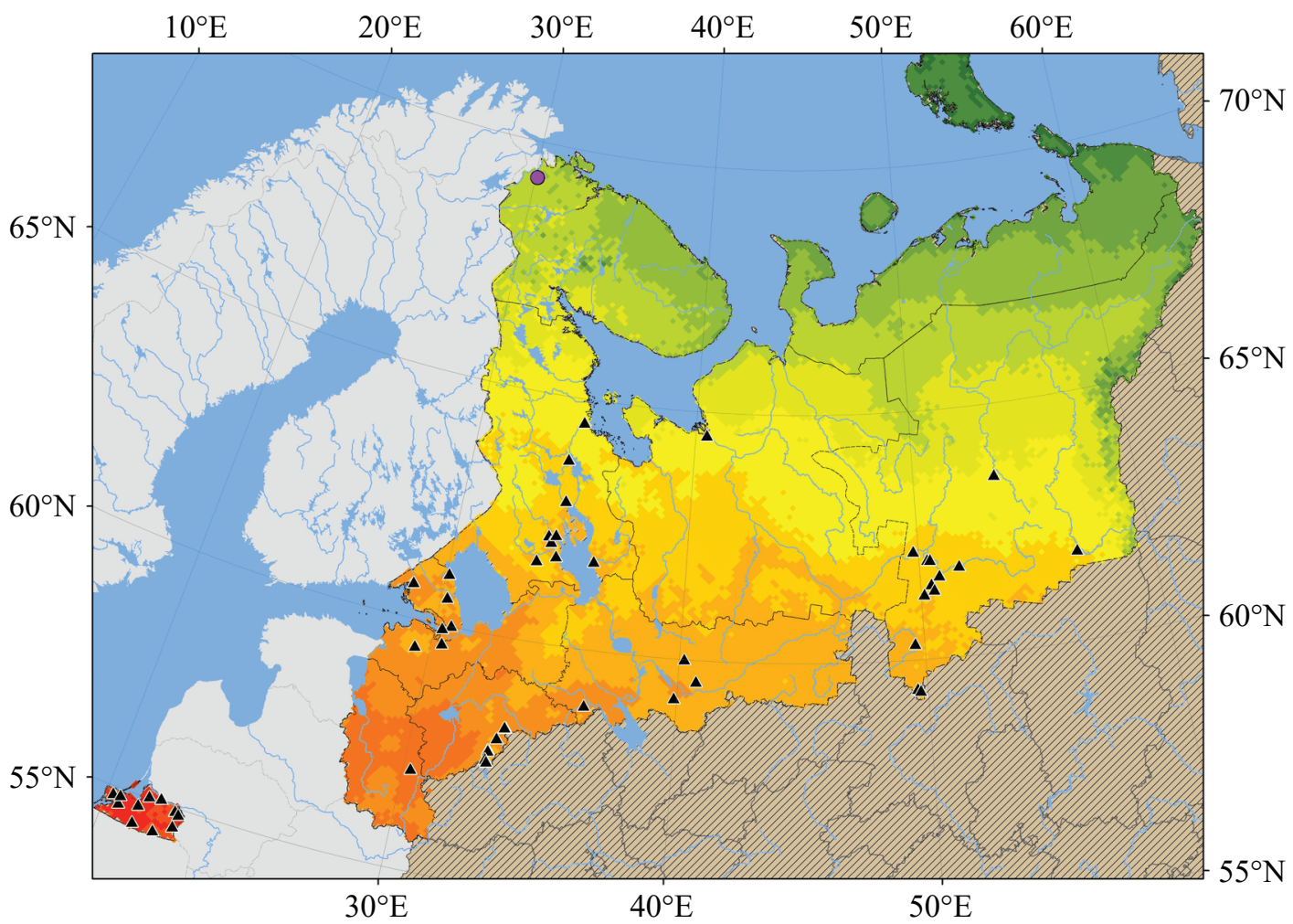

Fig. 5. Collection localities of Anopheles messeae Falleroni in Northwestern Russia. Designations as in Fig. 3. The location with doubtful species identification is shown in purple.

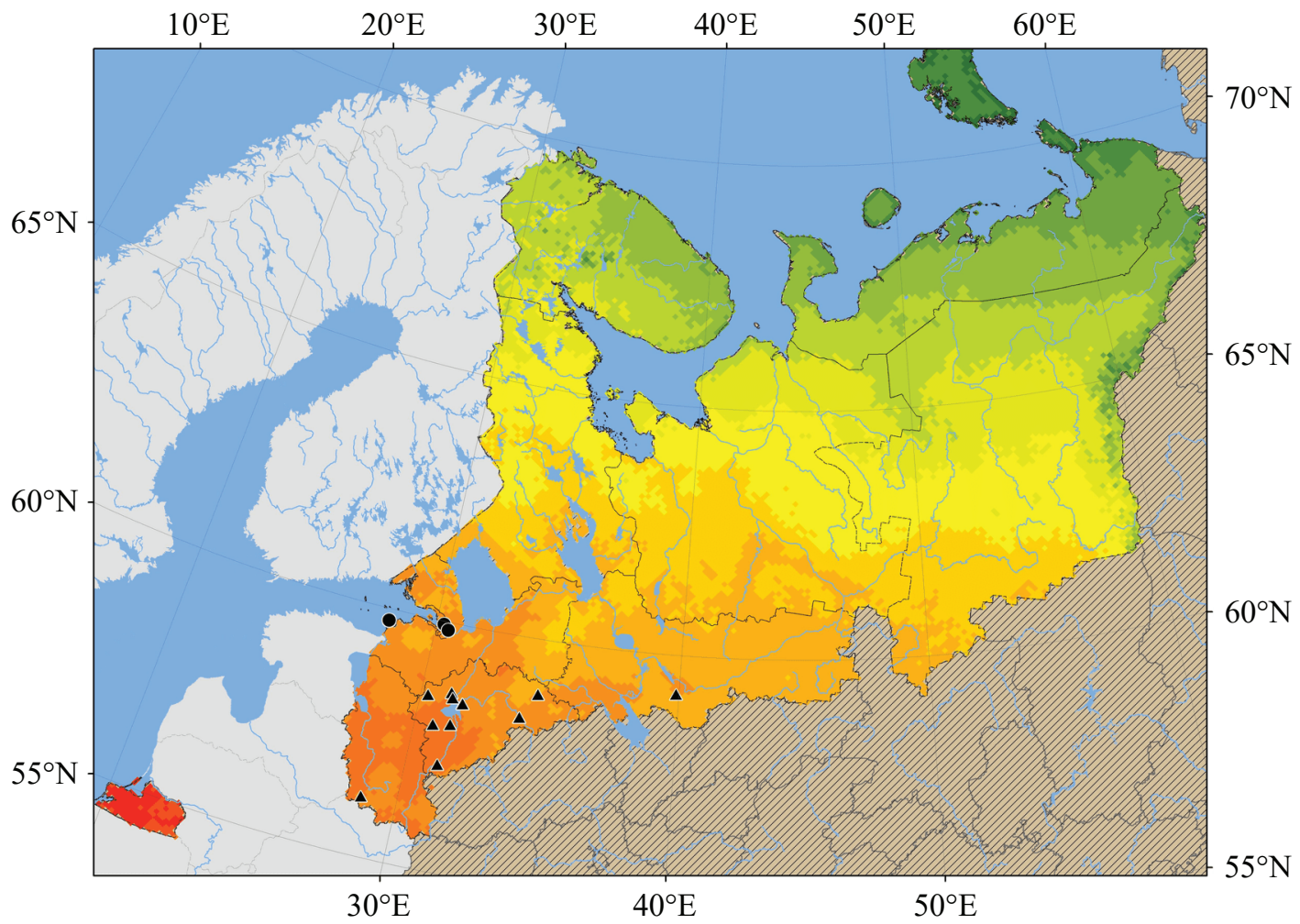

Fig. 6. Collection localities of Culex modestus Ficalbi in Northwestern Russia. Designations as in Fig. 3. 
MOSQUITO DISTRIBUTION IN NORTHWESTERN RUSSIA

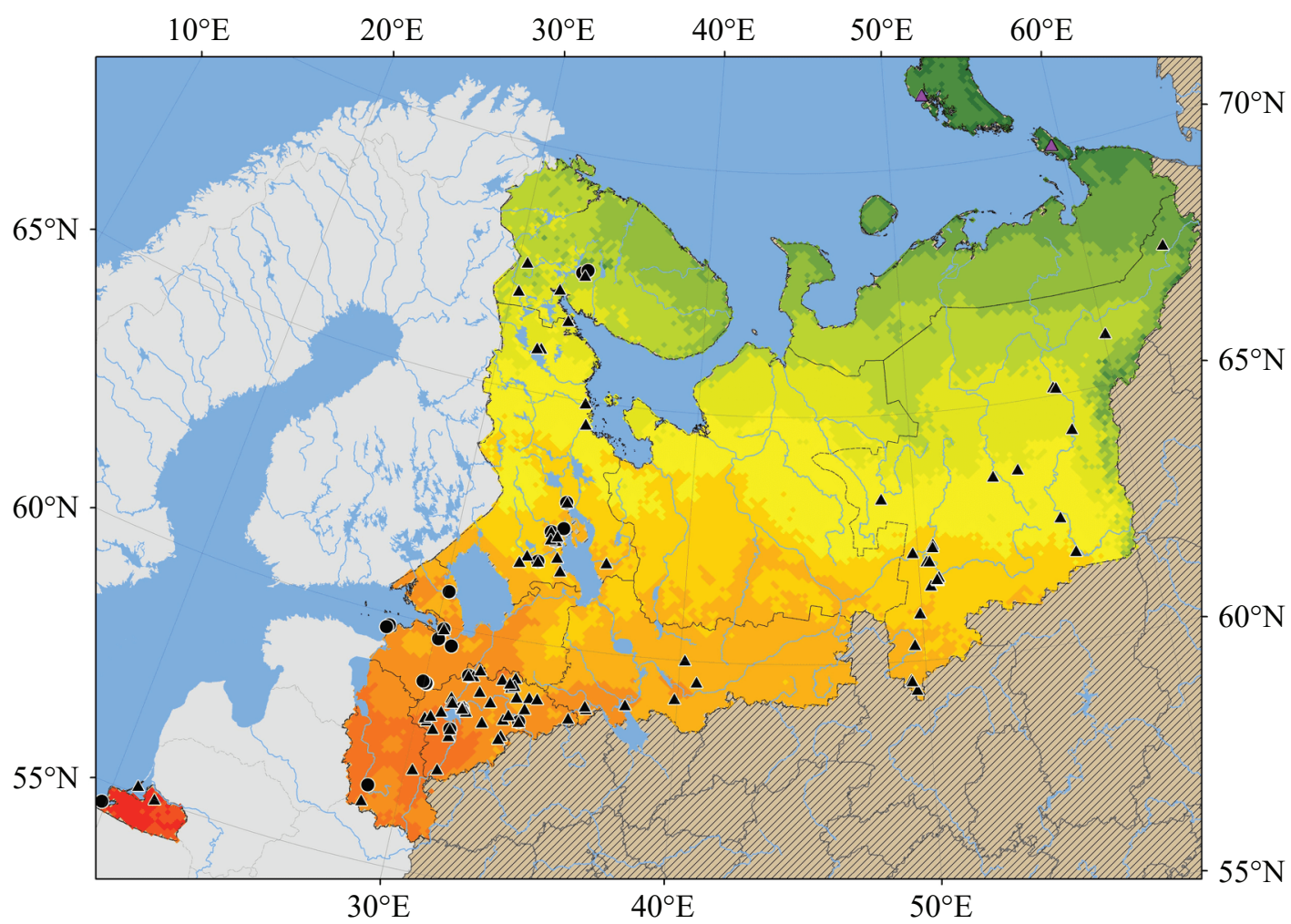

Fig. 7. Collection localities of Culex pipiens Linnaeus in Northwestern Russia. Designations as in Figs. 3, 5.

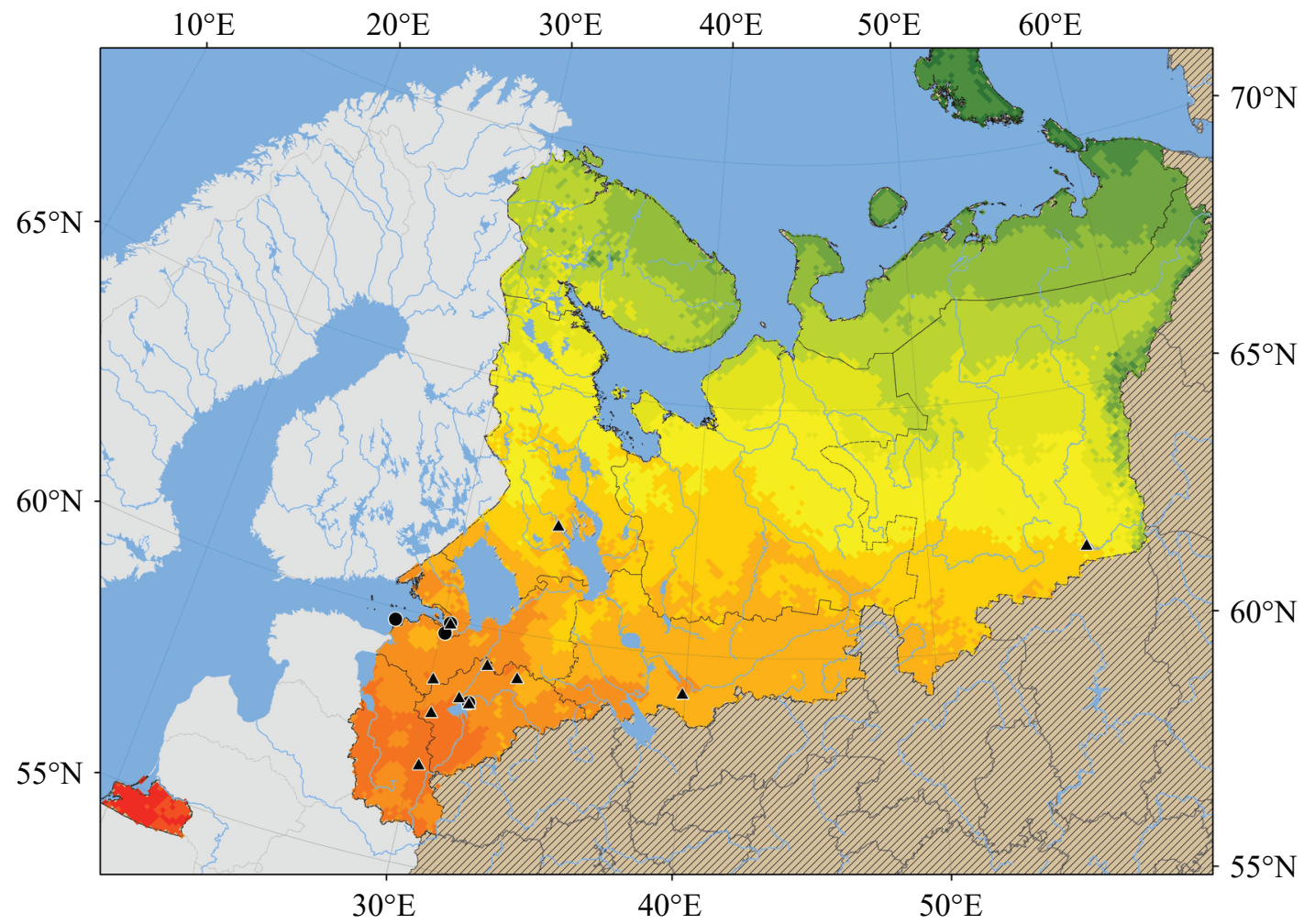

Fig. 8. Collection localities of Culex torrentium Martini in Northwestern Russia. Designations as in Fig. 3. 
Culex (Neoculex) territans Walker, 1856

Material. RK, SPb, LP, NP (Fig. 9).

Distribution. RK (Lobkova, 1964; Jakovlev et al., 2014). SPb (Fedorov, 1969). VP (Belova et al., 2008). Komi (Panyukova and Ostroushko, 2017). PP (Medvedev and Matov, 1999). NP (Panyukova and Medvedev, 2008).

Norway (Natvig, 1948; Mehl, 1996). Sweden (Natvig, 1948; Schäfer and Lundström, 2001; Lundström et al., 2013). Finland (Natvig, 1948; Utrio, 1977; Culverwell, 2018; Culverwell et al., 2021). Estonia (Remm, 1957). Lithuania (Pakalniskis et al., 2006).

European Russia, Siberia, the Russian Far East. Europe (ranging northward to the UK, Belgium, and Denmark); North Africa, Belarus, Moldova, West and Middle Asia; North America.

\section{Culiseta (Culisella) fumipennis}

(Stephens, 1825)

Material. RK, SPb, LP (Fig. 10).

Distribution. RK (Humala and Polevoi, 2009; Jakovlev et al., 2014). SPb (Gutsevich, 1948).

Norway (Natvig, 1948; Mehl, 1996). Sweden (Natvig, 1948; Schäfer and Lundström, 2001; Lundström et al., 2013). Estonia (Remm, 1957).

European Russia (north and west), south of West Siberia. Europe (ranging northward to the UK, Belgium, and Denmark); North Africa, Belarus, Ukraine, West Asia.

\section{Culiseta (Culisella) morsitans (Theobald, 1901)}

Material. MP, RK, SPb, LP, PP (Fig. 11).

Distribution. RK (Lobkova, 1964, 1965). SPb (Gutsevich, 1948; Fedorov, 1969). Komi (Ostroushko, 1986; Panyukova and Ostroushko, 2017). KP (Bernotiene, 2012). PP (Medvedev and Matov, 1999). NP (Panyukova and Medvedev, 2008).

Norway (Natvig, 1948; Mehl, 1996). Sweden (Natvig, 1948; Schäfer and Lundström, 2001; Lundström et al., 2013; Hesson et al., 2015; Möhlmann et al., 2017). Finland (Natvig, 1948; Utrio, 1977; Culverwell, 2018;
Culverwell et al., 2021). Estonia (Remm, 1957). Lithuania (Pakalniskis et al., 2006).

European Russia (northwest, west, center), south of West Siberia. Europe (ranging northward to the UK, Belgium, and Denmark); North Africa, Belarus, Ukraine, West Asia.

\section{Culiseta (Culisella) ochroptera (Peus, 1935)}

Material. RK, SPb, LP (Fig. 12).

Distribution. AP (Shevkunova and Gracheva, 1961). RK (Polevoi, 2006; Jakovlev et al., 2014). SPb (Fedorov, 1946, 1969). Komi (Panyukova and Ostroushko, 2017). KP (Bernotiene, 2012). NP (Panyukova and Medvedev, 2008).

Norway (Mehl, 1996). Sweden (Schäfer and Lundström, 2001; Lundström et al., 2013; Möhlmann et al., 2017). Finland (Utrio, 1977; Culverwell et al., 2021). Estonia (Remm, 1957). Lithuania (Pakalniskis et al., 2006).

European Russia, West Siberia, the Russian Far East. Europe (ranging northward to the Netherlands and Germany); Belarus, Ukraine, Northeast China.

Note. Shevkunova and Gracheva (1961) reported Culiseta ochroptera from AP but did not specify the exact collection locality. Since AP is a vast territory, we have not mapped this record in Fig. 12.

\section{Culiseta (Culiseta) alaskaensis (Ludlow, 1906)}

Material. MP, RK, SPb, LP, Komi (Fig. 13).

Distribution. MP (Shingareva, 1926; Gutsevich, 1934; Solovei and Likhoded, 1966; Tamarina and Aleksandrova, 1974; Sharkov, 1976, 1980a). AP (Edwards, 1921; Stackelberg, 1937; Sharkov, 1982). NAO (Monchadsky, 1950). RK (Shingareva, 1926; Natvig, 1948; Lobkova, 1956; Lobkova and Makarova, 1961; Jakovlev et al., 2014). SPb (Gutsevich, 1948; Fedorov, 1969). LP (Natvig, 1948; Taldrik, 1967). VP (Adrianov, 1953; Sharkov, 1982; Belova et al., 2008). Komi (Belokur, 1960; Beltyukova and Mitrofanova, 1971; Bryushinina, 1971; Potapov et al., 1972; Ostroushko, 1986; Panyukova and Ostroushko, 2017). KP (Bernotiene, 2012). PP (Medvedev and Matov, 1999). NP (Panyukova and Medvedev, 2008).

ENTOMOLOGICAL REVIEW Vol. 101 No. 32021 
MOSQUITO DISTRIBUTION IN NORTHWESTERN RUSSIA

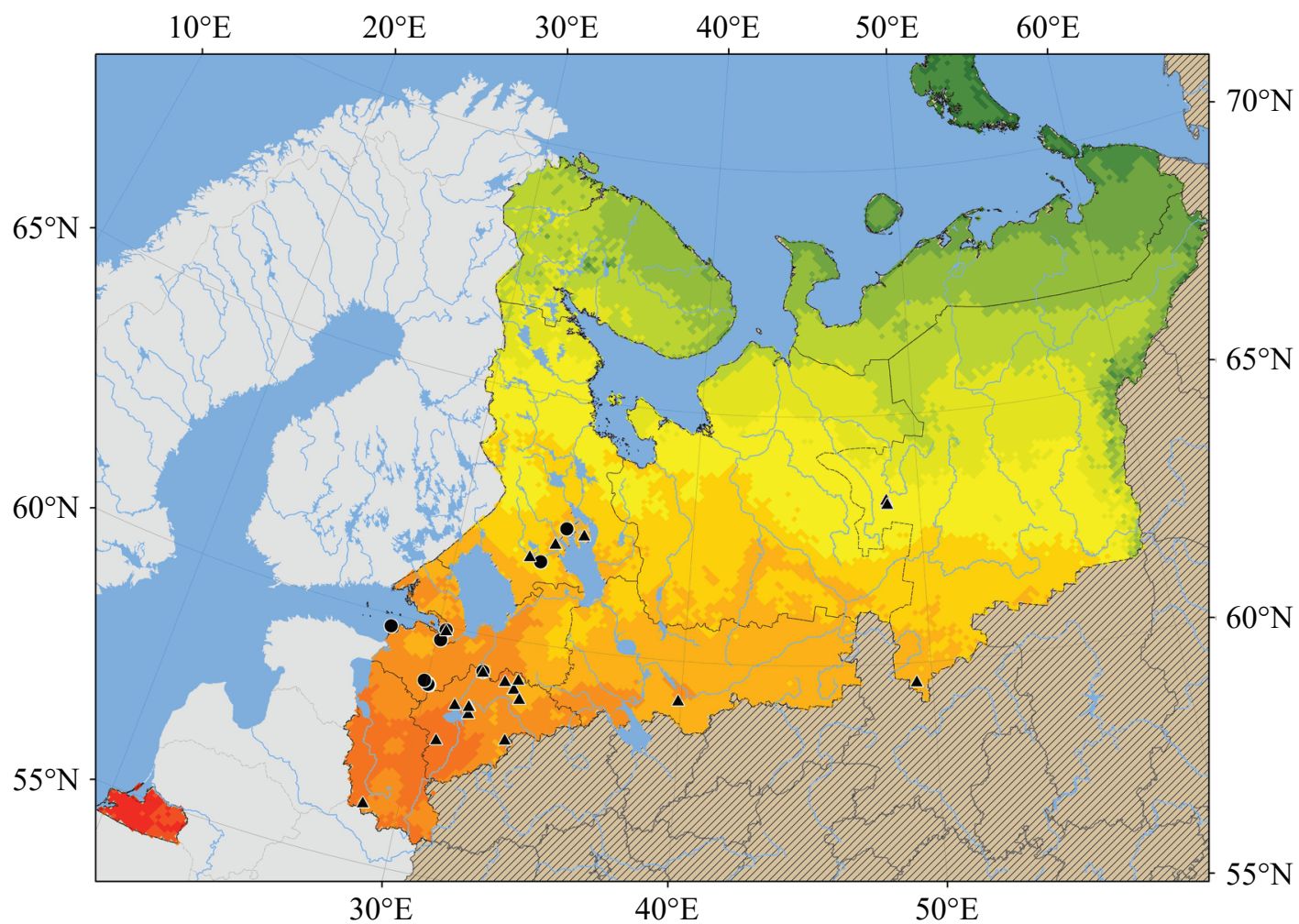

Fig. 9. Collection localities of Culex territans Walker in Northwestern Russia. Designations as in Fig. 3.

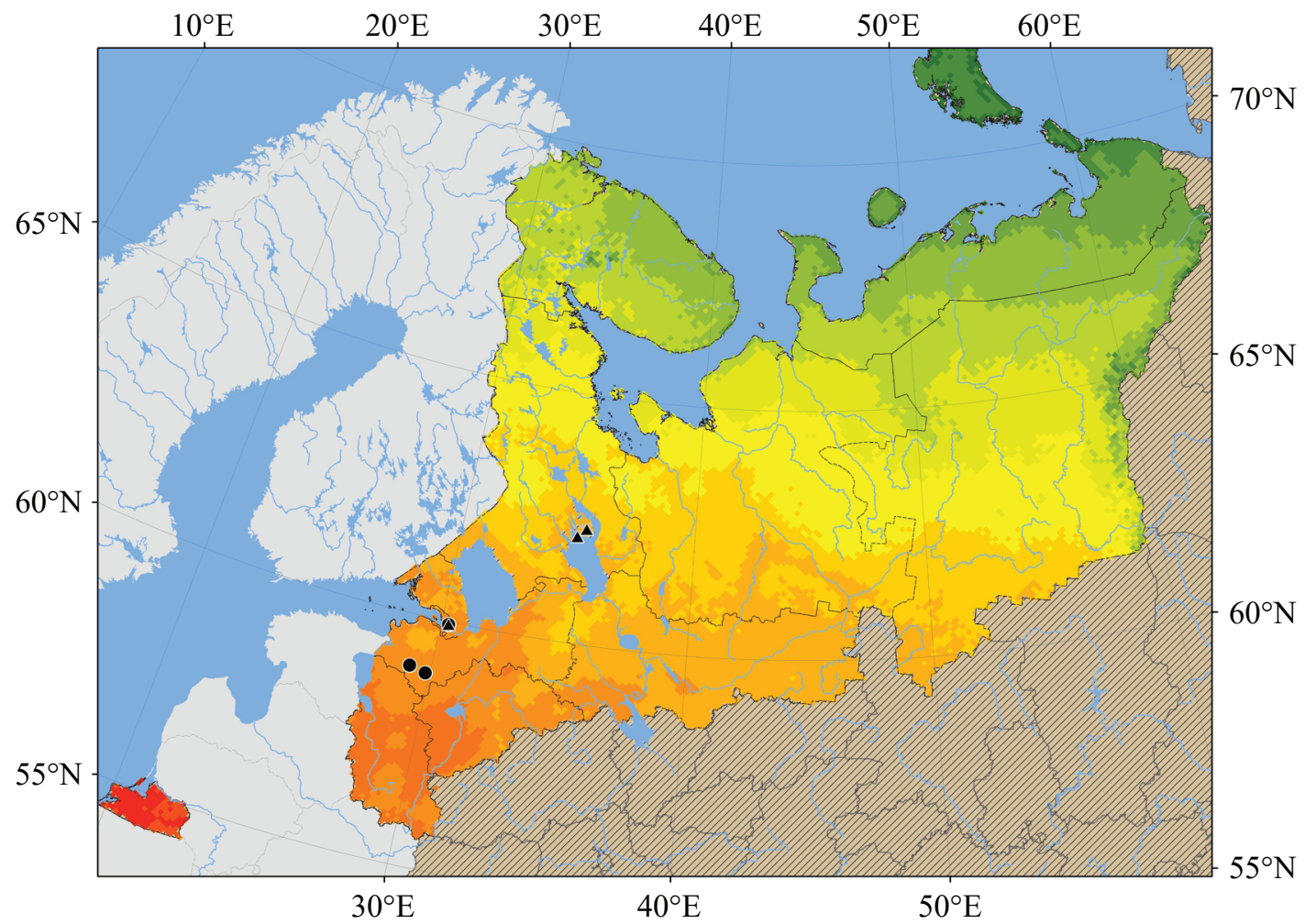

Fig. 10. Collection localities of Culiseta fumipennis (Stephens) in Northwestern Russia. Designations as in Fig. 3. 


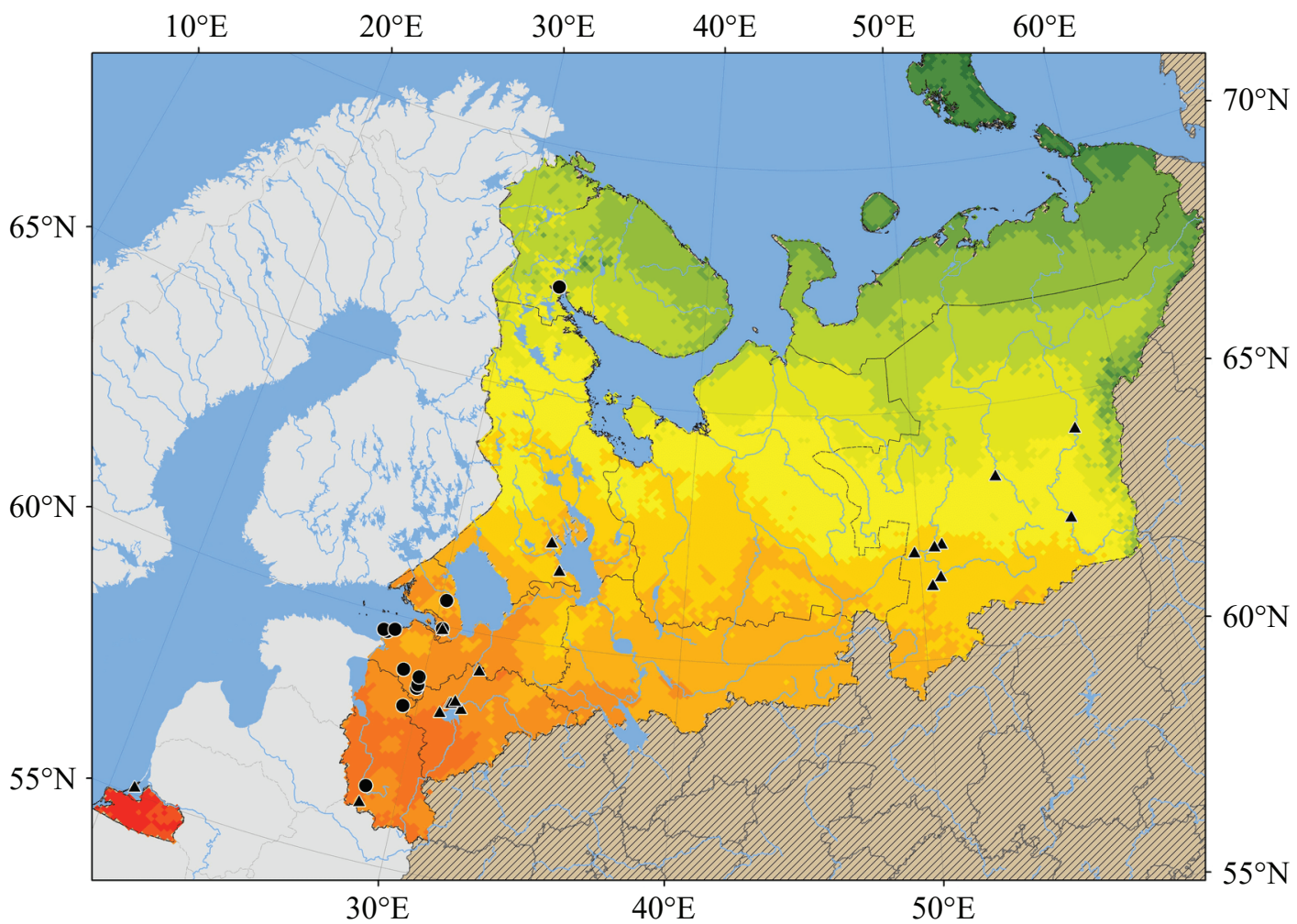

Fig. 11. Collection localities of Culiseta morsitans (Theobald) in Northwestern Russia. Designations as in Fig. 3.

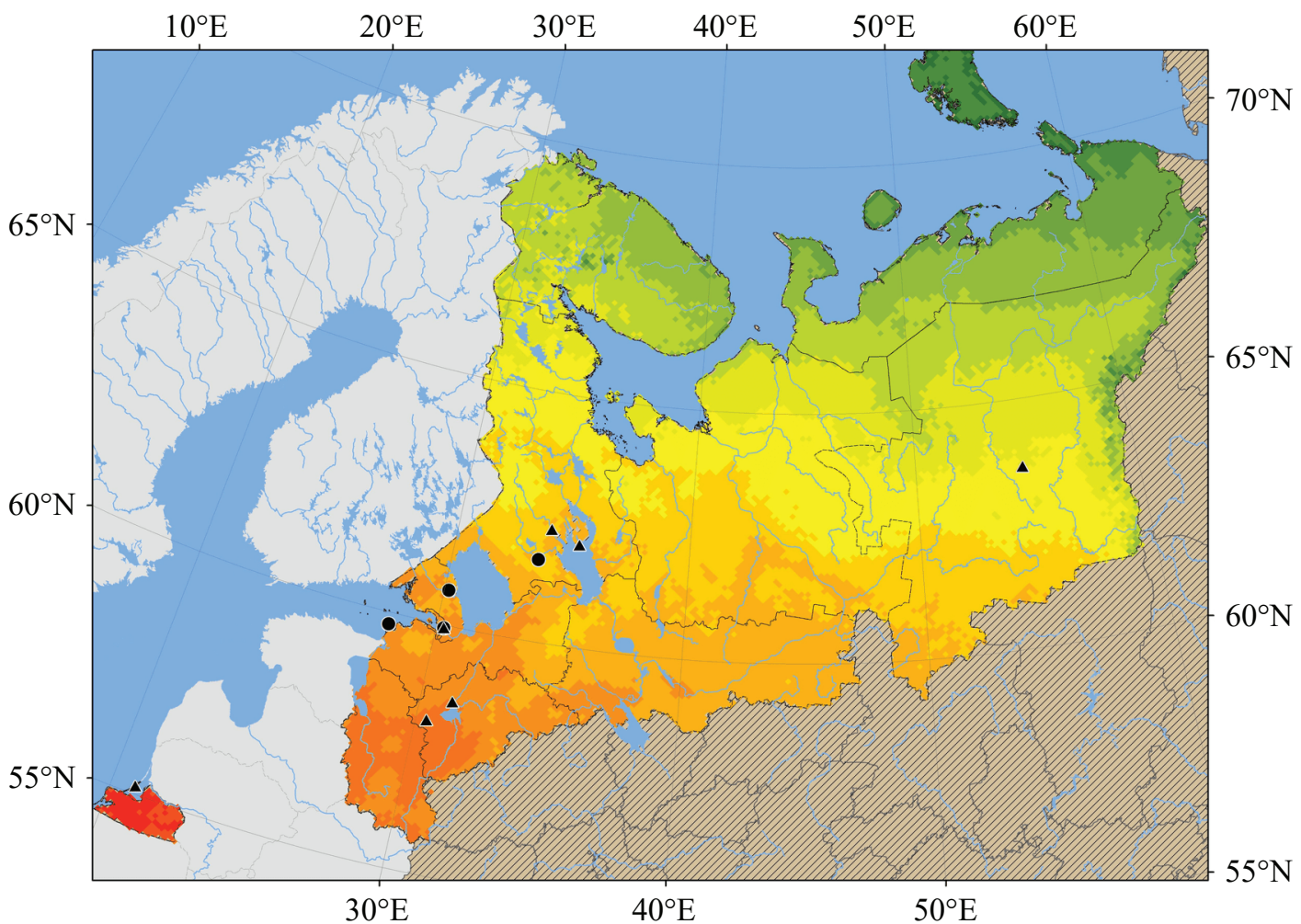

Fig. 12. Collection localities of Culiseta ochroptera (Peus) in Northwestern Russia. Designations as in Fig. 3. 
Norway (Natvig, 1948; Mehl, 1996). Sweden (Natvig, 1948; Schäfer and Lundström, 2001; Lundström et al., 2013; Möhlmann et al., 2017). Finland (Natvig, 1948; Utrio, 1977; Culverwell, 2018; Culverwell et al., 2021). Estonia (Remm, 1957). Latvia (Spungis, 2000). Lithuania (Pakalniskis et al., 2006).

European Russia, Siberia, the Russian Far East. Europe (ranging northward to the UK and the Netherlands); Belarus, Ukraine, Moldova; North America.

\section{Culiseta (Culiseta) annulata}

(Schrank, 1776)

Material. SPb, LP, KP (Fig. 14).

Distribution. SPb (Gutsevich, 1948; Fedorov, 1969). PP (Medvedev and Matov, 1999). NP (Panyukova and Medvedev, 2008).

Norway (Natvig, 1948; Mehl, 1996). Sweden (Natvig, 1948; Dahl, 1975; Schäfer and Lundström, 2001; Lundström et al., 2013; Möhlmann et al., 2017). Finland (Utrio, 1977; Culverwell, 2018; Culverwell et al., 2021). Estonia (Remm, 1957). Latvia (Spungis, 2000). Lithuania (Pakalniskis et al., 2006).

European Russia (west and northwest), Siberia, the Russian Far East. Europe (ranging northward to the UK, Belgium, and Denmark); North Africa, Belarus, Ukraine, Moldova, Transcaucasia, Asia Minor, Kazakhstan, Middle Asia.

\section{Culiseta (Culiseta) bergrothi}

(Edwards, 1921)

Material. MP, RK, SPb, LP, Estonia (Fig. 15).

Distribution. MP (Shingareva, 1926; Stackelberg, 1937; Rumsh, 1948; Solovei and Likhoded, 1966; Tamarina and Aleksandrova, 1974; Sharkov, 1980a, 1980b). AP (Sharkov, 1982). RK (Lobkova, 1956; Jakovlev et al., 2014). VP (Sharkov, 1982; Belova et al., 2008). Komi (Ostroushko, 1986; Panyukova and Ostroushko, 2017). PP (Medvedev and Matov, 1999).

Norway (Natvig, 1948; Mehl, 1996). Sweden (Natvig, 1948; Schäfer and Lundström, 2001; Lundström et al., 2013; Möhlmann et al., 2017). Finland (Natvig, 1948; Utrio, 1977; Culverwell et al., 2021). Estonia (Maslov, 1967).
European Russia (north and west), Siberia, the Russian Far East. Europe (Denmark), Kazakhstan, Mongolia, North China, Korea, Japan.

Coquillettidia richiardii (Ficalbi, 1889)

Material. RK, SPb, LP, PP, NP (Fig. 16).

Distribution. RK (Lobkova, 1956; Jakovlev et al., 2014). SPb (Gutsevich, 1948; Fedorov, 1969). LP (Taldrik, 1967). Komi (Panyukova and Ostroushko, 2017). KP (Levenson et al., 1959; Bernotiene, 2012). PP (Medvedev and Matov, 1999). NP (Fedorova, 1977; Panyukova and Medvedev, 2008).

Norway (Mehl, 1996). Sweden (Natvig, 1948; Schäfer and Lundström, 2001; Lundström et al., 2013; Möhlmann et al., 2017). Finland (Natvig, 1948; Utrio, 1977; Culverwell, 2018; Culverwell et al., 2020). Estonia (Remm, 1957). Latvia (Spungis, 2000). Lithuania (Pakalniskis et al., 2006).

European Russia, West Siberia. Europe (ranging northward to the UK, Belgium, and Denmark); North Africa, Belarus, Ukraine, Moldova, Asia Minor, Kazakhstan, Middle Asia.

\section{DISCUSSION}

Analysis of additional publications has allowed us to correct the mosquito check-list in NWR, currently comprising 47 species; the list was supplemented with Anopheles atroparvus, recorded in KP (Levenson et al., 1959). In the course of the examination of the records of species of the genera Anopheles, Coquillettidia, Culex, and Culiseta in comparison with the SAT parameter, the minimal SAT values for each species within NWR were determined (Table 2) and the position of the northern range boundaries of these species was analyzed. Based on our material and the ZIN collections, the northern distribution boundaries in NWR were updated for five species: Anopheles claviger, A. messeae, Culiseta morsitans, Culex territans, and C.modestus. Based on the minimal SAT values, species of the genera Anopheles, Coquillettidia, Culex, and Culiseta were included in four groups (Fig. 17).

Group 1. Three species: Culex pipiens, Culiseta alaskaensis, and C. bergrothi. These species are distributed in the area with SAT values exceeding $770^{\circ} \mathrm{C}$ (i.e., the whole territory of NWR excluding the north and east of 


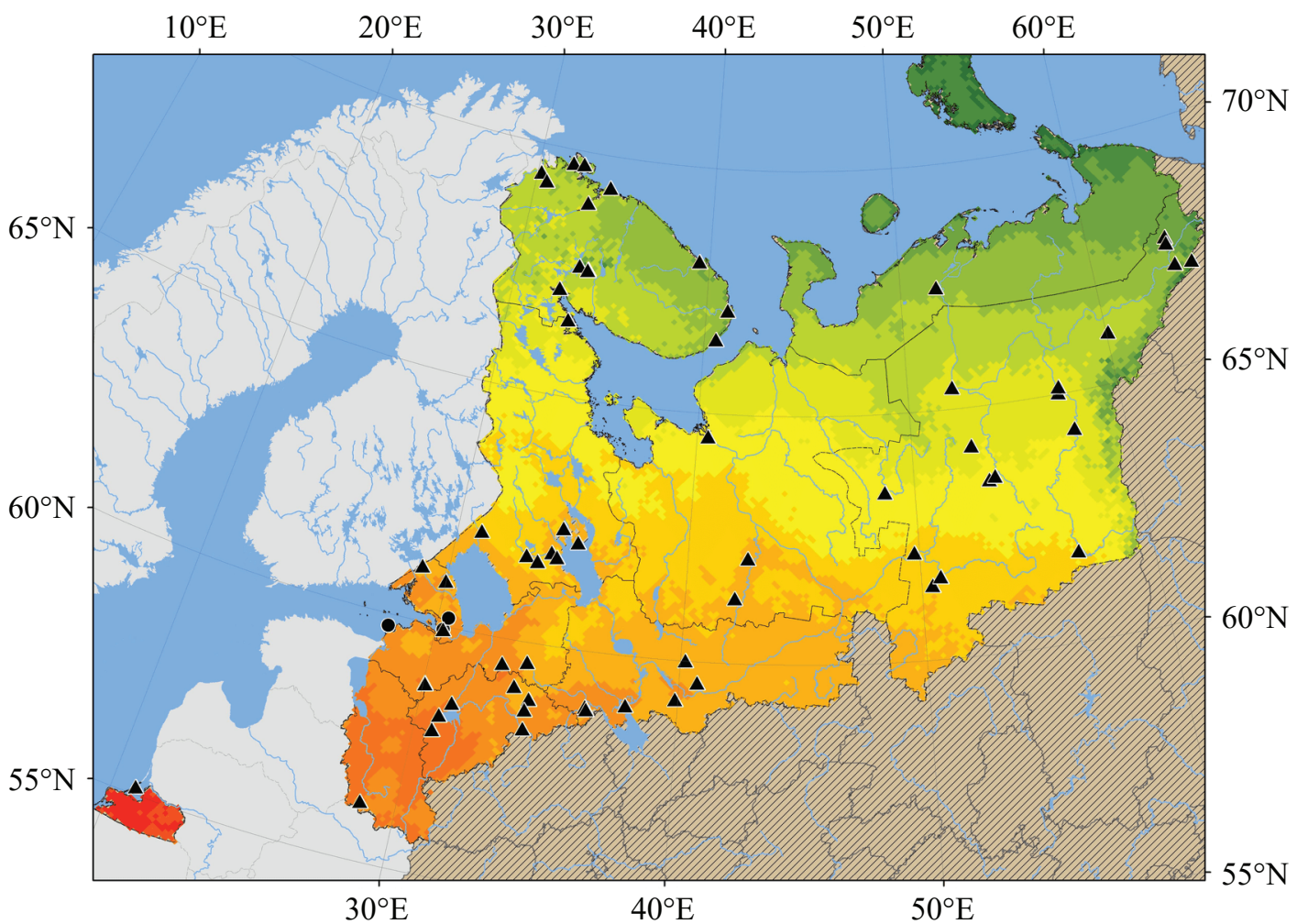

Fig. 13. Collection localities of Culiseta alaskaensis (Ludlow) in Northwestern Russia. Designations as in Fig. 3.

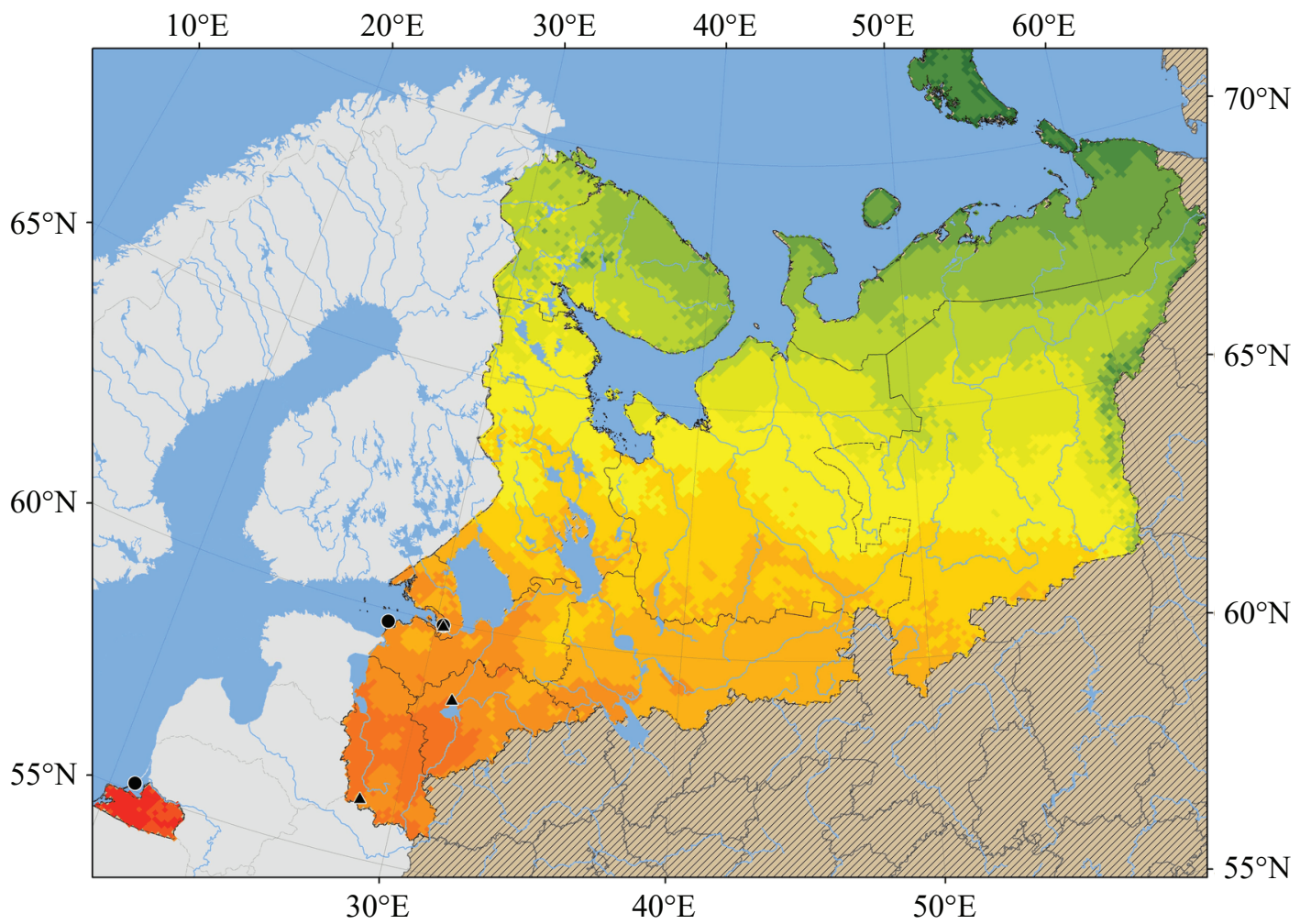

Fig. 14. Collection localities of Culiseta annulata (Schrank) in Northwestern Russia. Designations as in Fig. 3. 


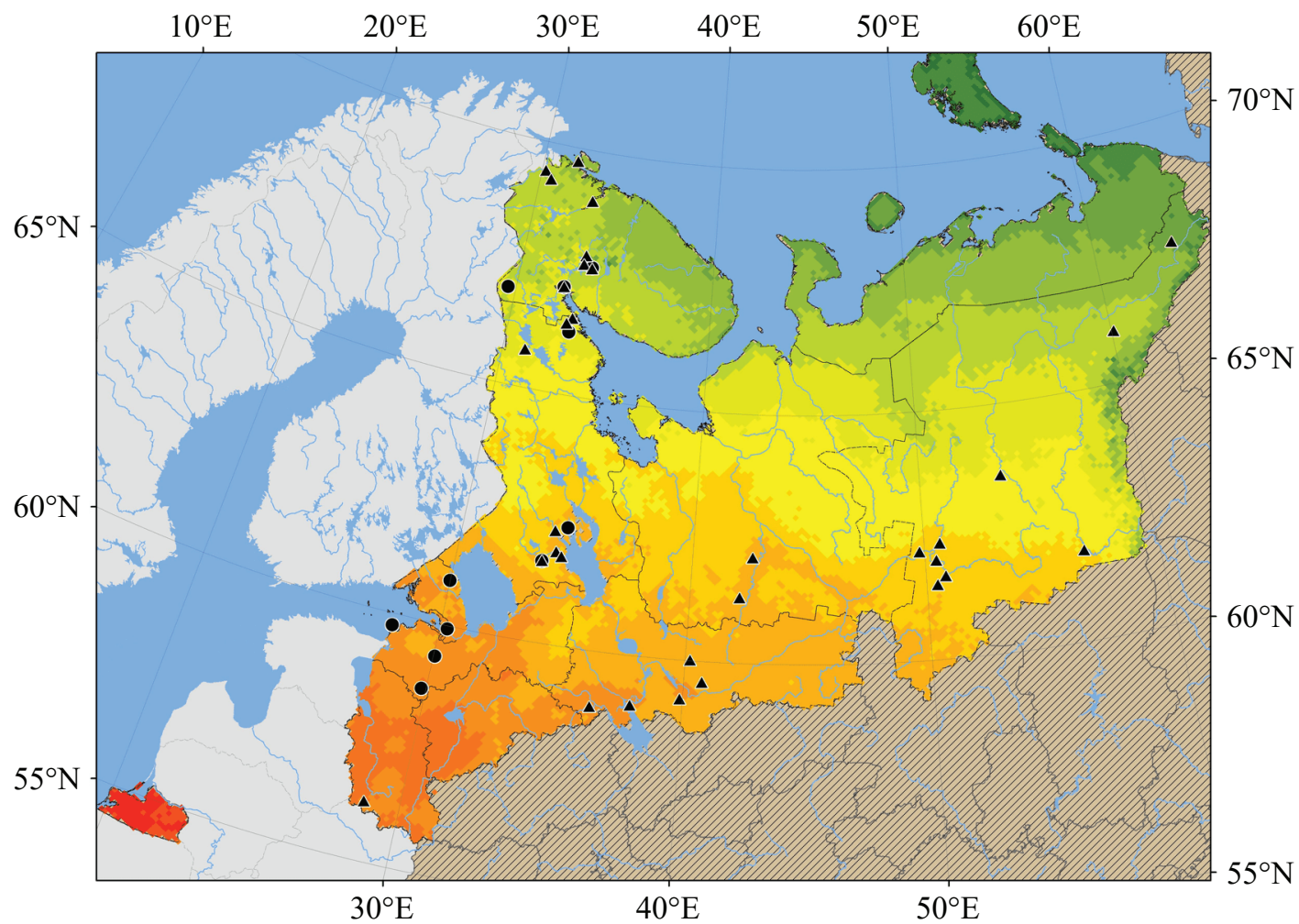

Fig. 15. Collection localities of Culiseta bergrothi (Edwards) in Northwestern Russia. Designations as in Fig. 3.

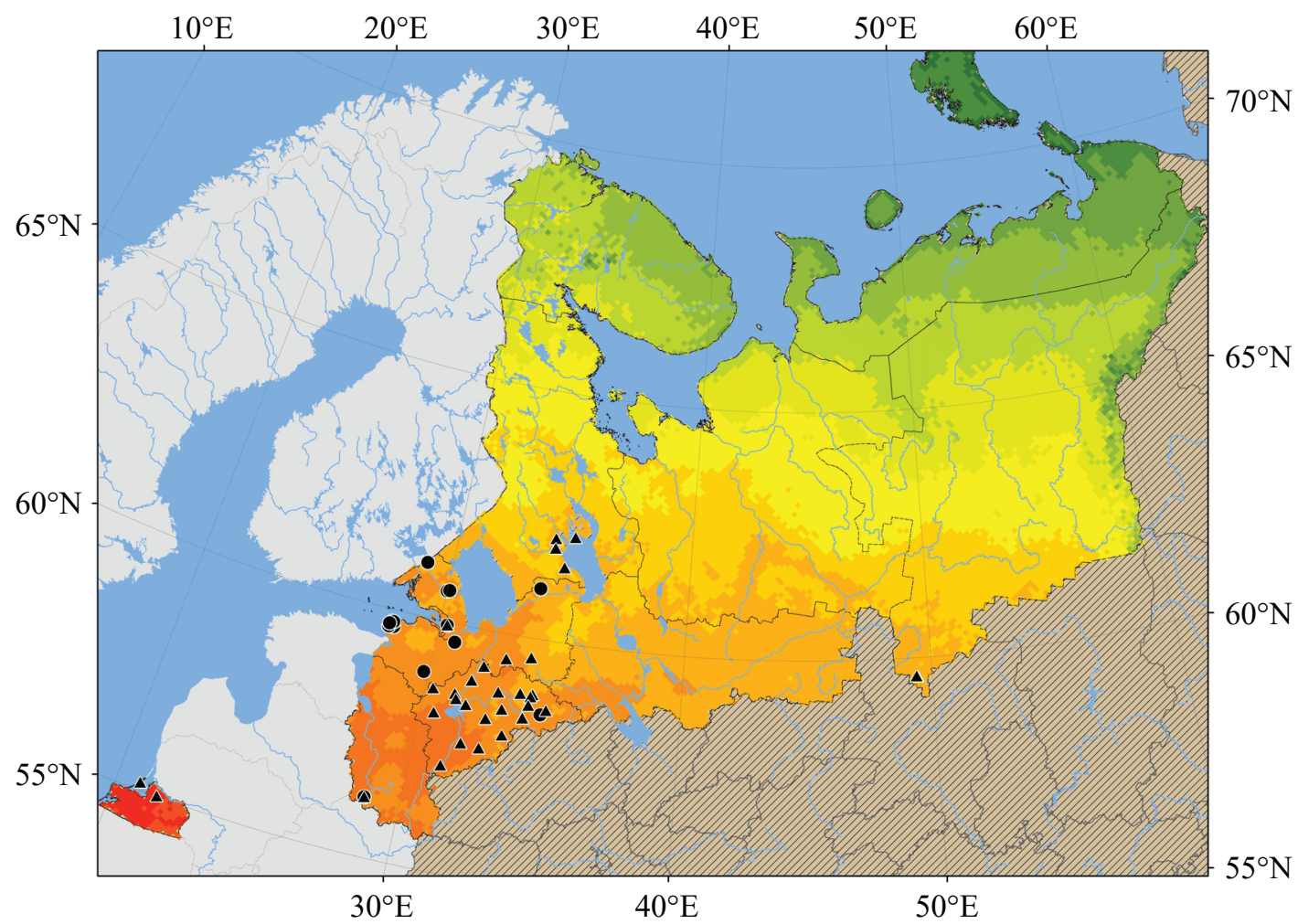

Fig. 16. Collection localities of Coquillettidia richiardii (Ficalbi) in Northwestern Russia. Designations as in Fig. 3. 
Table 2. Minimal values of the sums of active temperatures above $0^{\circ} \mathrm{C}$ for mosquito species in Northwestern Russia

\begin{tabular}{l|c|c}
\hline \multicolumn{1}{c|}{ Species } & Min SAT, ${ }^{\circ} \mathrm{C}$ & Group \\
\hline Culiseta alaskaensis & 775.5 & \\
C. bergrothi & 848.3 & 1 \\
Culex pipiens & 848.3 & \\
\hline Culiseta morsitans & 1227.8 & \\
C. ochroptera & 1490.6 & \\
Anopheles beklemishevi & 1577.2 & 2 \\
A. maculipennis & 1577.2 & \\
A. messeae & 1577.2 & \\
Culex territans & 1587.1 & \\
\hline Culex torrentium & 1733.2 & \\
Anopheles claviger & 1863.6 & \\
Culiseta fumipennis & 1951.0 & 3 \\
Coquillettidia richiardii & 1966.7 & \\
\hline Culex modestus & 2112.3 & \\
Culiseta annulata & 2226.4 & 4 \\
Anopheles atroparvus & 2721.8 & \\
\hline
\end{tabular}

Each group includes all the species of the former group, i.e., group 2 includes group 1; group 3 includes groups 1 and 2; group 4 comprises all the 16 mosquito species.

NAO and the insular part of AP; see Fig. 17). No species of the genera Anopheles, Coquillettidia, Culex, and Culiseta have been reliably recorded in the territories of NWR with SAT values below $770^{\circ} \mathrm{C}$.

Group 2. Nine species, including 3 species of group 1 and also Anopheles beklemishevi, A. maculipennis, A. messeae, Culex territans, Culiseta morsitans, and C. ochroptera. These species are distributed in the area with SAT values exceeding $1227^{\circ} \mathrm{C}$ (i.e., the territory of NWR excluding the greatest parts of MP and NAO and the north and east of the Komi Republic; see Fig. 17). The northernmost locality of Culiseta morsitans differs considerably from those of the remaining species in a lower SAT value (see Table 2). The records with SAT $1577.2^{\circ} \mathrm{C}$ are probably located near the northern distribution boundary of Anophelinae mosquitoes in NWR; as compared with this value, the record of an Anopheles mosquito in MP (Shuioniioki River, SAT $1136.4^{\circ} \mathrm{C}$ ) is quite unexpected.
Group 3. Thirteen species: all the examined species excluding Anopheles atroparvus, Culex modestus, and Culiseta annulata. Mosquitoes of this group are distributed in the area with SAT values exceeding $1733^{\circ} \mathrm{C}$ (KP, LP, south of RK, AP, Komi, VP, PP, and NP). Coquillettidia richiardii is the only species of its genus in the North Palaearctic; correspondingly, the locality with a SAT value of $1966.7^{\circ} \mathrm{C}$ probably lies at the northern distribution boundary of the genus Coquillettidia in NWR.

Group 4. Sixteen species: all the species studied here. They are distributed in the area with SAT values exceeding $2112^{\circ} \mathrm{C}$ : KP, south and west of LP, PP, most of NP, and south of VP. For instance, Culex modestus was found in the south of VP (SAT $2112.3^{\circ} \mathrm{C}$ and higher), and Culiseta annulata was recorded in SPb (SAT over $2226.4^{\circ} \mathrm{C}$ ). Anopheles atroparvus was the most thermophilous of all the 16 species in the NWR fauna: it was found only in the west of KP (SAT over $2721.8^{\circ} \mathrm{C}$ ).

Mosquitoes are amphibiotic insects whose larvae and pupae develop in temporary and permanent water bodies, while the adults are terrestrial. The larvae and adults of most mosquito species are not trophically specialized to any plant or animal species; therefore, the ranges of species of the family Culicidae do not directly follow those of other organisms. The distribution of some mosquito species may be limited by the presence of water bodies suitable for their larvae. NWR occupies a large territory with a total area of over $1.5 \mathrm{mln} \mathrm{km}^{2}$, diverse climatic conditions, and a wide range of ecozones, from Arctic deserts to mixed forests. At the same time, in NWR there are no large arid or highland regions which could prevent the spreading of mosquitoes. Consequently, the SAT value in the collection locality appears to be an adequate climatic parameter reflecting the main features of the life cycle of mosquito species.

NWR includes some territories with relatively wellstudied faunas of mosquitoes (e.g., MP, RK, SPb, and Komi) and also regions poorly studied in this respect (KP, AP, and NAO). In some cases, comparison of the northern distribution boundaries and the corresponding SAT values may be used to extrapolate the range boundary onto still unstudied territories. For example, the records of Culiseta bergrothi in the north of MP and the northeast of Komi (SAT $848.3^{\circ} \mathrm{C}$ ) indicate that the species may be distributed over the largest part of NAO and AP. The records of Culiseta morsitans in MP and Komi 


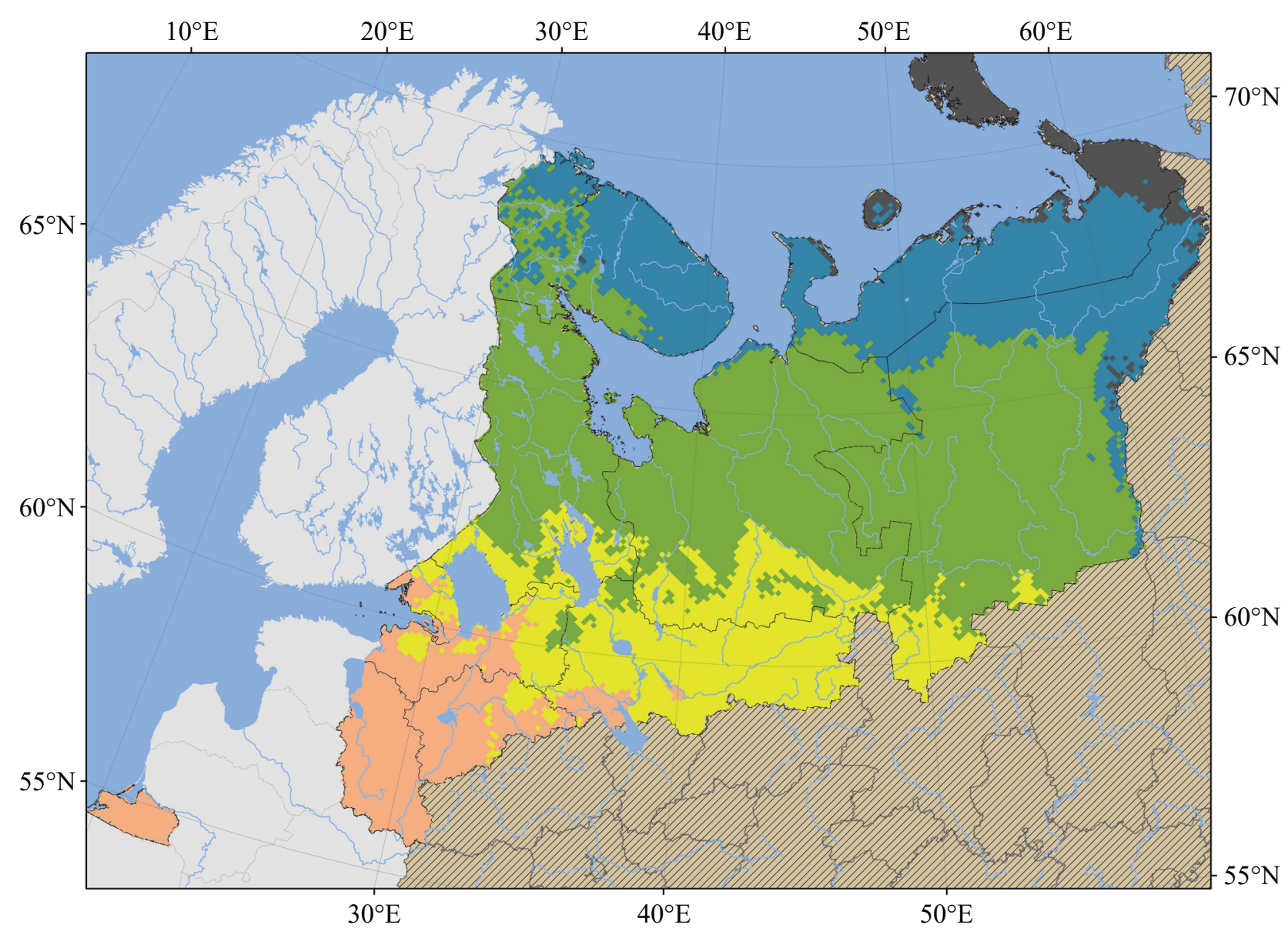

Territory where none of the studied Culicidae species were recorded

Territory where only species of group 1 occur

Territory where only species of groups 1 and 2 occur

Territory where only species of groups 1,2 , and 3 occur

Territory where all the studied Culicidae species occur

Fig. 17. Distribution of groups of Culicidae species in Northwestern Russia. The composition of groups $1-4$ is explained in the text.

(SAT $1227.8^{\circ} \mathrm{C}$ ) indicate that the species may also occur in the continental parts of AP and VP, while the records of Coquillettidia richiardii in RK and Komi (SAT $1966.7^{\circ} \mathrm{C}$ ) suggest its presence in VP.

The northward expansion of a mosquito species may be limited not only by the number of days with a temperature sufficient for its preimaginal development and adult activity, but also by the low winter temperatures eliminating the insects during diapause. Most mosquitoes distributed in the high latitudes of the Holarctic (e.g., Aedes species) overwinter in the egg stage, but the northernmost species considered herein, Culiseta alaskaensis and C. bergrothi, diapause as adult females; yet this feature does not prevent them from spreading as far northwards as the Barents Sea coast.

\section{CONCLUSIONS}

Comparison of the species records and the SAT values for the collection localities was used to extrapolate the northern distribution boundaries of mosquito species in NWR. The northern range boundaries in different mosquito species were found to vary significantly within 
the NWR territory, corresponding to the SAT values from 775.5 to $2721.8^{\circ} \mathrm{C}$. For instance, the northern range boundaries of the closely related species Culiseta alaskaensis and $C$. annulata are located far apart: in the north of MP and Komi (SAT $775.5^{\circ} \mathrm{C}$ ) in the former and in $\mathrm{SPb}\left(\mathrm{SAT} 2226.4^{\circ} \mathrm{C}\right)$ in the latter. The mosquito species present in NWR can be included in four groups according to the common trends in their distribution. For example, the northernmost localities of mosquitoes from different genera: Culiseta fumipennis and Coquillettidia richiardii, and also Culex territans and Anopheles messeae, have nearly identical SAT values: from 1951.0 to $1966.7^{\circ} \mathrm{C}$ and from 1577.2 to $1587.1^{\circ} \mathrm{C}$, respectively.

The results of this research may be used for species distribution modelling of such important vectors as Anopheles maculipennis, A. messeae, Culex pipiens, C. modestus, and Coquillettidia richiardii.

\section{FUNDING}

This work was based on the taxonomic collection of ZIN and financially supported by the Additional State Assignment AAAA-A17-117030310209-7.

\section{COMPLIANCE WITH ETHICAL STANDARDS}

The authors declare that they have no conflict of interest. All the applicable international, national, and/or institutional guidelines for the care and use of animals were followed. All the procedures performed in studies involving animals were in accordance with the ethical standards of the institution or practice at which the studies were conducted.

\section{OPEN ACCESS}

This article is licensed under a Creative Commons Attribution 4.0 International License, which permits use, sharing, adaptation, distribution and reproduction in any medium or format, as long as you give appropriate credit to the original author(s) and the source, provide a link to the Creative Commons license, and indicate if changes were made. The images or other third party material in this article are included in the article's Creative Commons license, unless indicated otherwise in a credit line to the material. If material is not included in the article's Creative Commons license and your intended use is not permitted by statutory regulation or exceeds the permitted use, you will need to obtain permission directly from the copyright holder. To view a copy of this license, visit http://creativecommons.org/licenses/by/4.0/.

\section{REFERENCES}

Adrianov, S.I., Observations of mosquitoes, Med. Parazitol. Parazit. Bolezni, 1953, vol. 6, p. 559.

Afonin, A.N., Green, S.L., Dzyubenko, N.I., and Frolov, A.N., Interactive Agricultural Ecological Atlas of Russia and Neighboring Countries: Economic Plants and Their Diseases, Pests and Weeds, 2008.

http://www.agroatlas.ru/

Aibulatov, S.V. and Khalin, A.V., Mosquitoes (Diptera: Culicidae) of Northwestern Russia, in Aktual'nye problemy biologicheskoi i khimicheskoi ekologii. Sbornik materialov VI Mezhdunarodnoi nauchno-prakticheskoi konferentsii (Current Problems of Biological and Chemical Ecology: Proc. of 4th Int. Conf.), Petrenko, D.B., Moscow: Mosk. Gos. Oblast. Univ., 2019, p. 85.

Aibulatov, S.V., Khalin, A.V., and Filonenko, I.V., Features of the mosquito distribution (Diptera, Culicidae) in Northwestern Russia, in XI Vserossiiskii dipterologicheskii simpozium (s mezhdunarodnym uchastiem) (The 11th All-Russian Dipterological Symposium with International Participation), Ovtshinnikova, O.G. and Shamshev, I.V., Eds., St. Petersburg: Lema, 2020, p. 21.

https://doi.org/10.47640/978-5-00105-586-0_2020_21

Alkhovsky, S.V., Taxonomy of zoonotic viruses of the families Bunyaviridae, Flaviviridae, Reoviridae, Orthomyxoviridae, Togaviridae, Picornaviridae, and Arteriviridae, isolated in North Eurasia, Extended Abstract of Doctoral Dissertation in Biology, Moscow, 2016.

Becker, N., Petric, D., Zgomba, M., Boase, C., Madon, M., Dahl, C., and Kaiser, A., Mosquitoes and Their Control, 2nd $E d$., Heidelberg etc.: Springer, 2010.

https://doi.org/10.1007/978-3-540-92874-4_15

Beklemishev, V.N., Vinogradskaya, O.N., Derbeneva-Ukhova, V.P., Dolmatova, A.V., Kuzina, O.S., Olifan, V.I., PospelovaShtrom, M.V., and Shipitsina, N.K., Uchebnik meditsinskoi entomologii (Manual of Medical Entomology), Part 1, Moscow: Medgiz, 1949.

Belokur, V.M., On the fauna of bloodsucking dipterans of Nenets Autonomous Okrug and the north of Komi ASSR, Entomol. Obozr., 1960, vol. 39, no. 2. p. 404.

Belova, Yu.N., Dolganova, M.N., Kolesova, N.S., Shabunov, A.A., and Filonenko, I.V., Raznoobrazie nasekomykh Vologodskoi oblasti (Insect Diversity in Vologda Province), Vologda: Kopernik, 2008.

ENTOMOLOGICAL REVIEW Vol. 101 No. 32021 
Beltyukova, K.N. and Mitrofanova, Yu.G., Bloodsucking Diptera in the shrub tundra of the Polar Urals, Uch. Zap. Perm. Gos. Univ., 1971, vol. 249, p. 158.

Bernotiene, R., The fauna and seasonal activity of mosquitoes (Diptera: Culicidae) in the Curonian Spit (Russia, Lithuania), Eur. Mosquito Bull., 2012, vol. 30, p. 72.

Bryushinina, G.T., Species composition and phenology of the main bloodsucking dipteran taxa in the northern taiga subzone of Komi ASSR, Tr. Vses. Nauchno-Issled. Inst. Veter. Med., 1971, vol. 40, p. 204.

Chetverikova, T.G., Blood-sucking Diptera (Culicidae, Tabanidae) in the protected territory of the Polistovsky Nature Reserve and adjacent areas, in Sovremennye tendentsii razvitiya osobo okhranyaemykh prirodnykh territorii, Materialy nauchno-prakticheskoi konferentsii (Modern Trends in the Specially Protected Natural Areas: Proc. of Conf.), Velikie Luki, 2014, p. 203.

Culverwell, C.L., A report on the mosquitoes of mainland Åland, southwestern Finland and revised list of Finnish mosquitoes, Med. Vet. Entomol., 2018, vol. 32, no. 2, p. 145. https://doi.org/10.1111/mve.12272

Culverwell, C.L., Uusitalo, R.J., Korhonen, E.M., Vapalahti, O., Huhtamo, E., and Harbach, R.E., The mosquitoes of Finland: updated distributions and bionomics, Med. Vet. Entomol., 2021, vol. 45 , no. 1 , p. 1 .

https://doi.org/10.1111/mve.12475

Dahl, C., Culicidae (Dipt. Nematocera) of the Baltic island of Öland, Entomol. Tidskr., 1975, vol. 96, no. 3, p. 77.

Dahl, C., Verification of Anopheles (An.) messeae Falleroni (Culicidae, Dipt.) from Southern Sweden, Entomol. Tidskr., 1977, vol. 98, p. 149.

De Meijere, J.C.H., Die Dipteren der arktischen Inseln (Eine Zusammenstellung der arktischen Tierformen mit besonderer Berücksichtigung des Spitzbergen-Gebietes auf Grund der Ergebnisse der Deutschen Expedition in das Nördliche Eismeer im Jahre 1898), in Fauna Arctica, Vol. 5, Issue 1, Römer, F., Schaudinn, F., and Brauer, A., Eds., 1910, p. 15.

Edwards, F.W., A revision of the mosquitoes of the Palaearctic Region, Bull. Entomol. Res., 1921, vol. 12, p. 263.

https://doi.org/10.1017/S0007485300040207

Fedorov, V.G., On the finding of Culex molestus Forskal in Leningrad, Med. Parazitol., 1946, vol. 15, no. 2, p. 58.

Fedorov, V.G., Species composition of mosquitoes (Diptera, Culicidae) in Leningrad, Med. Parazitol. Parazit. Bolezni, 1969, vol. 38, no. 6, p. 720.

Fedorova, V.G., Fauna and ecology of adult mosquitoes (Diptera, Culicidae) in Novgorod Province, Med. Parazitol. Parazit. Bolezni, 1977, vol. 46, no. 5, p. 574.
Gordeev, M.I. and Moskaev, A.V., Dynamics of the chromosomal composition of Anophelinae mosquito populations in the Komi Republic under the conditions of climate warming, in Sbornik tezisov dokladov uchastnikov VI s"ezda Vavilovskogo obshchestva genetikov i selektsionerov (VOGiS) i assotsiirovannye geneticheskie simpoziumy. Rostov-na-Donu, 15.06-20.06.2014 (The 6th Congress of the Vavilov Society of Geneticists and Breeders and the Associated Genetic Symposia, Rostov-on-Don, June 15-20, 2014), Novosibirsk: Sibir. Otdel. Ross. Akad. Nauk, 2014, p. 7.

Gutsevich, A.V., On mosquitoes from the Khibiny Mountains, Parazitol. Sb., 1934, no. 4, p. 5.

Gutsevich, A.V., Observations of mosquitoes in the environs of Leningrad, Tr. Voen.-Med. Akad., 1948, vol. 44, p. 61.

Gutsevich, A.V., Monchadsky, A.S., and Stackelberg, A.A., Fauna SSSR. Nasekomye dvukrylye (Fauna of the USSR. Dipterous Insects), Vol. 3, Issue 4: Komary sem. Culicidae (Mosquitoes of the Family Culicidae), Leningrad: Nauka, 1970.

Hesson, J.C., Verner-Carlsson, J., Larsson, A., Ahmed, R., Lundkvist, Å., and Lundström, J.O., Culex torrentium mosquito role as major enzootic vector defined by rate of Sindbis virus infection, Sweden, 2009, Emerging Infect. Dis. J., 2015, vol. 21 , no. 5 , p. 875.

https://doi.org/10.3201/eid2105.141577

Humala, A.E. and Polevoi, A.V., On the insect fauna of southeastern Karelia, Tr. Karel. Nauchn. Tsentra Ross. Akad. Nauk, 2009, no. 4, p. 53.

Jakovlev, J., Polevoi, A., and Humala, A., Insect fauna of Zaonezhye Peninsula and adjacent islands, in Biogeography, Landscapes, Ecosystems and Species of Zaonezhye Peninsula, in Lake Onega, Russian Karelia, Lindholm, T., Jakovlev, J., and Kravchenko, A., Eds., Helsinki: Finnish Environment Institute, 2014, p. 257.

Khalin, A.V. and Aibulatov, S.V., Fauna of blood-sucking insects of the gnus complex in the Northwestern Region of Russia. III. Mosquitoes (Culicidae), Entomol. Rev., 2020, vol. 100 , no. 1 , p. 58 .

https://doi.org/10.1134/S0013873820010066

Khalin, A.V. and Aibulatov, S.V., Northernmost records of the mosquito species (Diptera: Culicidae) in the Northwestern Russia, Zoosyst. Ross., 2021, vol. 30, no. 1, p. 46.

https://doi.org/10.31610/zsr/2021.30.1.46

Khalin, A.V. and Gornostaeva, R.M., On the taxonomic composition of mosquitoes (Diptera: Culicidae) in the World and Russian fauna (critical review), Parazitologiya, 2008, vol. 42, no. 5, p. 360 .

Korenberg, E.I., Biokhorologicheskaya struktura vida (The Biochorological Structure of a Species), Moscow: Nauka, 1975. 
Kunkova, E.V., On the fauna of mosquitoes of the family Culicidae in Valdaysky National Park, in Materialy regional'noi nauchnoi konferentsii "Issledovaniya na okhranyaemykh territoriyakh Severo-Zapada Rossii" (Research in Protected Territories of Northwestern Russia: Proc. of the Regional Conf.), Veliky Novgorod: Novgorod. Gos. Univ., 2000, p. 332.

Kunkova, E.V. and Fedorova, V.G., Addition to the fauna of mosquitoes of the family Culicidae (Diptera) of Novgorod Province, Parazitologiya, 2003, vol. 37, no. 2, p. 113.

Levenson, E.D., Vinogradskaya, O.I., Aptekar, S.A., and Netsengevich, M.R., Specific epidemiological features of malaria in Kaliningrad Province, in Trudy Instituta meditsinskoi parazitologii i tropicheskoi meditsiny imeni E.I. Martsinovskogo (Proceedings of E.I. Martsinovsky Institute of Medical Parasitology and Tropical Medicine), Moscow, 1959, p. 137.

Lobkova, M.P., Observation data on mosquitoes in Karelian ASSR, Uch. Zap. Petrozavodsk. Univ., 1956, vol. 7, no. 3, p. 211.

Lobkova, M.P., Some data on the distribution of mosquitoes (subfamily Culicinae) in Karelia, in K prirodnoi ochagovosti parazitarnykh $i$ transmissivnykh zabolevanii $v$ Karelii (Natural Focality of Parasitic and Transmissible Diseases in Karelia), Lutta, A.S., Ed., Moscow: Nauka, 1964, p. 100.

Lobkova, M.P., Mosquitoes, in Fauna ozer Karelii. Bespozvonochnye (The Lake Fauna of Karelia: Invertebrates), Polyansky, Yu.I., Ed., Moscow: Nauka, 1965, p. 230.

Lobkova, M.P., Ecology and biology of Culex pipiens L. in Karelia, in Krovososushchie chlenistonogie evropeiskogo Severa (Blood-Sucking Arthropods in the European North), Lutta, A.S., Ed., Petrozavodsk: Akad. Nauk SSSR, 1980, p. 80 .

Lobkova, M.P. and Makarova, M.P., Morphological changes in the larval instars of some mosquitoes of the subfamily Culicinae, in Trudy Karel'skogo filiala Akademii nauk SSSR. Vyp. 30. Voprosy parazitologii Karelii (Proceedings of the Karelian Branch of the USSR Academy of Sciences, Issue 30: Problems of Parasitology in Karelia), Lutta, A.S., Ed., Petrozavodsk: Gos. Izdat. Karel. ASSR, 1961, p. 129.

Lundström, J.O., Schäfer, M.L., Hesson, J.C., Blomgren, E., Lindström, A., Wahlqvist, P., Halling, A., Hagelin, A., Ahlm, C., Evander, M., Broman, T., Forsman, M., and Vinnersten, T.Z., The geographic distribution of mosquito species in Sweden, J. Eur. Mosquito Control Assoc., 2013, vol. 31, p. 21.

Lvov, D.K., Klimenko, S.M., and Guydamovich, S.Ya., Arbovirusy $i$ arbovirusnye infektsii (Arboviruses and Arboviral Infections), Moscow: Meditsina, 1989.

Maslov, A.V., Krovososushchie komary podtriby Culisetina (Diptera, Culicidae) mirovoi fauny (Mosquitoes of the Sub- tribe Culisetina (Diptera, Culicidae) in the World Fauna), Leningrad: Nauka, 1967.

Medvedev, S.G. and Matov, A.Yu., Fauna of ticks and bloodsucking insects of the southwestern Pskov Province, Prir. Pskov. Kraya, 1999, vol. 8, p. 3.

Medvedev, S.G. and Panyukova, E.V., Landscape distribution of mosquitoes of the family Culicidae (Diptera) in Novgorod Province, Entomol. Obozr., 2005, vol. 84, no. 4, p. 776.

Medvedev, S.G., Aibulatov, S.V., Bespyatova, L.A., Brodskaya, N.K., Panyukova, E.V., Khalin, A.V., and Yankovsky, A.V., Bloodsucking dipteran insects (Diptera) attacking humans and animals (the "gnus" complex) in Northwestern Russia: I. General characteristics of the fauna, Entomol. Obozr., 2007, vol. 86, no. 4, p. 827.

Mehl, R., Culicidae Stikkmygg, in Limnofauna Norvegica: katalog over norsk ferskvannsfauna, Aagaard, K. and Dolmen, D., Eds., Trondheim: Tapir, 1996, p. 202.

Möhlmann, T.W.R., Wennergren, U., Tälle, M., Favia, G., Damiani, C., Bracchetti, L., and Koenraadt, C.J.M., Community analysis of the abundance and diversity of mosquito species (Diptera: Culicidae) in three European countries at different latitudes, Parasites Vectors, 2017, vol. 10, no. 1, p. 1.

https://doi.org/10.1186/s13071-017-2481-1

Monchadsky, A.S., Mosquito attacks on humans under the Subarctic natural conditions and factors controlling it, Parazitol. Sb., 1950, no. 12, p. 123.

Moshkovsky, Sh.D. and Rashina, M.G., Epidemiologiya $i$ meditsinskaya parazitologiya dlya entomologov (Epidemiology and Medical Parasitology for Entomologists), Moscow: Medgiz, 1951.

Moskaev, A.V., Gordeev, M.I., Nikolaev, V.I., and Moskaeva, T.S., The main water divide and the karyological composition of Anopheles mosquito populations in Novgorod and Tver provinces, in Izuchenie i okhrana prirodnogo $i$ istoricheskogo naslediya Valdaiskoi vozvyshennosti $i$ sopredel'nykh regionov. Materialy mezhregional'noi nauchnoprakticheskoi konferentsii (Study and Protection of the Nature and Historical Heritage of the Valday Upland and Adjacent Regions: Proc. Interregional Conf.), Vyshny Volochyok, 2015, p. 255.

Moskaev, A.V., Gordeev, M.I., and Ganushkina, L.L., The species and karyological composition of malaria-transmitting mosquitoes in different natural and climatic zones of Leningrad Province, Med. Parazitol. Parazit. Bolezni, 2016, no. 3, p. 36.

Natvig, L.R., Contributions to the knowledge of the Danish and Fennoscandian mosquitoes - Culicini, Norsk Entomol. Tidsskr., 1948, Suppl. 1, p. 1.

ENTOMOLOGICAL REVIEW Vol. 101 No. 32021 
Osten-Sacken, R.R., On the current state of knowledge of the insect fauna in the vicinity of St. Petersburg, Zh. Minist. Narod. Prosv., 1858, vol. 48, no. 2, p. 1.

Ostroushko, T.S., Mosquitoes of the middle taiga of the Komi Republic, Tr. Komi Fil. Akad. Nauk SSSR, 1986, vol. 74 , p. 61.

Ozerov, A.S., On the finding of Culex molestus (Forskål) in Vologda, Med. Parazitol. Parazit. Bolezni, 1957, vol. 27, no. 1, suppl., p. 55.

Pakalniskis, S., Bernotiene, R., Lutovinovas, E., Petrasiunas, A., Podenas, S., Rimsaite, J., Saeter, O.A., and Spungis, V., Checklist of Lithuanian Diptera, New Rare Lith. Ins. Species, 2006, vol. 18, p. 16.

Panyukova, E.V., The fauna of mosquitoes (Diptera, Culicidae) of the Pechora-Ilych nature reserve (Komi Republic), Entomol. Rev., 2019, vol. 99, no. 1, p. 64.

https://doi.org/10.1134/S0013873819010093

Panyukova, E.V. and Medvedev, S.G., Species composition and ecological features of mosquitoes of the genera Culex, Culiseta, and Coquillettidia (Diptera, Culicidae) in Novgorod Province, Parazitologiya, 2008, vol. 42, no. 5, p. 382.

https://doi.org/10.1134/S0031184718060054

Panyukova, E.V. and Ostroushko, T.S., Fauna evropeiskogo severo-vostoka Rossii (Fauna of the Northeast of European Russia), Vol. 11, Part 2: Krovososushchie komary (Mosquitoes (Diptera: Culicidae)), Moscow: KMK Scientific Press, 2017.

Pavlovsky, E.N., On the fauna of ectoparasites of Leningrad Province, in Vrediteli zhivotnovodstva (Livestock Pests), Pavlovsky, E.N., Ed., Moscow: Akad. Nauk SSSR, 1935, p. 339.

Pavlovsky, E.N., Prirodnaya ochagovost' transmissivnykh boleznei (Natural Focal Structure of Transmissible Diseases), Moscow: Nauka, 1964.

Perevozkin, V.P., Gordeev, M.I., Moskaev, A.V., Ahmetova, N.M., and Bondarchuk, S.S., Inversion polymorphism and ecological specialization of malaria mosquitoes (Diptera, Culicidae) in Karelia, Genetika, 2012, vol. 48, no. 7, p. 806.

Perevozkin, V.P., Bondarchuk, S.S., and Kormilitsin, A.V., Cytogenetic analysis of malaria mosquitoes of Kaliningrad Province, Genetika, 2018, vol. 54, no. 2, p. 211.

https://doi.org/10.7868/S0016675818020145

Polevoi, A.V., New data on the Diptera fauna of Kivach Reserve, Tr. Karel. Nauchn. Tsentra Ross. Akad. Nauk, 2006, no. 10 , p. 95.

Popova, E.N. and Popov, I.O., Climatic factors determining the range boundaries of agricultural pests and pathogens and computational methods of assessment of changes in their dis- tribution following the climate change, Probl. Ekol. Monit. Model. Ekosist., 2013, vol. 25, p. 177.

Potapov, A.A., Bogdanova, E.N., and Vladimirova, V.V., Fauna and seasonal and daily activity of blood-sucking dipterans in Udorskii District of the Komi ASSR: observation data of 1970, Med. Parazitol. Parazit. Bolezni, 1972, vol. 41, no. 1, p. 21.

Remm, Kh.Ya., On the fauna and ecology of mosquitoes (Diptera, Culicidae) of Estonian SSR, Entomol. Obozr., 1957, vol. 36 , no. 1 , p. 148.

Robert, V., Günay, F., Le Goff, G., Boussès, P., Sulesco, T., Khalin, A., Medlock, J.M., Kampen, H., Petrić, D., and Schaffner, F., Distribution chart for Euro-Mediterranean mosquitoes (western Palaearctic region), J. Eur. Mosq. Control Assoc., 2019, vol. 37, p. 1.

Rumsh, L.T., Mosquitoes in the north of the USSR, Parazitol. Sb., 1948, no. 10, p. 87.

Sack, P., Dipteren aus Nowaja Semlja, in Report of the Scientific Results of the Norwegian Expedition to Novaya Zemlya 1921, No. 15, Holtendahl, O., Ed., Kristiania, 1923, p. 1.

Schäfer, M. and Lundström, J.O., Comparison of mosquito (Diptera: Culicidae) fauna characteristics of forested wetlands in Sweden, Ann. Entomol. Soc. Am., 2001, vol. 94, no. 4, p. 576.

https://doi.org/10.1603/0013-8746(2001)094[0576:COMD$\mathrm{CF}] 2.0 . \mathrm{CO} ; 2$

Sharkov, A.A., Species composition and distribution of mosquitoes in Murmansk Province, in Parazitologicheskie issledovaniya v Karel'skoi ASSR i Murmanskoi oblasti (Parasitological Studies in Karelian ASSR and Murmansk Province), Petrozavodsk, 1976, p. 62.

Sharkov, A.A., Krovososushchie komary (Diptera, Culicidae) Murmanskoi oblasti (Mosquitoes (Diptera, Culicidae) of Murmansk Province), Petrozavodsk, 1980a.

Sharkov, A.A., Ecology of mosquitoes of Kildin Island and the Sredny and Rubachy peninsulas (Murmansk Province), in Krovososushchie chlenistonogie evropeiskogo Severa (BloodSucking Arthropods in the European North), Lutta, A.S., Ed., Petrozavodsk: Akad. Nauk SSSR, 1980b, p. 102.

Sharkov, A.A., Specific features of mosquito (Culicidae) distribution in Arkhangelsk and Vologda provinces, Med. Parazitol. Parazit. Bolezni, 1982, vol. 51, no. 1, p. 51.

Sharkov, A.A., Lobkova, M.P., and Usova, Z.V., Krovososushchie komary i moshki evropeiskogo Severa SSSR (Bloodsucking Mosquitoes and Blackflies in the European North of the USSR), Petrozavodsk, 1984.

Shevkunova, E.A. and Gracheva, L.I., Materials on the fauna and ecology of mosquitoes in Arkhangelsk Province, Med. Parazitol. Parazit. Bolezni, 1961, vol. 30, no. 2, p. 228. 
Shingareva, A.I., Incidence of malaria in the Murmansk railroad area, Med. Zh., 1926, vol. 9, p. 43.

Shub, G.M. and Nikolaev, B.P., On the northern boundary of malaria distribution in Leningrad Province, Med. Parazitol. Parazit. Bolezni, 1937, vol. 6, no. 1, p. 56.

Solovei, V.Ya. and Likhoded, V.G., On the fauna and biology of bloodsucking Diptera in the northwest of Murmansk Province, Entomol. Obozr., 1966, vol. 45, no. 3, p. 565.

Spungis, V., A checklist of Latvian mosquitoes (Diptera, Culicidae), Eur. Mosq. Bull., 2000, vol. 6, p. 8.

Stackelberg, A.A., Fauna SSSR. Nasekomye dvukrylye (Fauna of the USSR. Insecta, Diptera), Vol. 3, Issue 4: Semeistvo Culicidae (Family Culicidae), Moscow: Akad. Nauk SSSR, 1937.

Stegnii, V.N., Novikov, Yu.M., and Kabanova, V.M., Cytogenetic analysis and distribution of the malaria mosquito Anopheles beklemishevi, Zool. Zh., 1978, vol. 57, no. 6, p. 873.

Suslo, D.S., The mosquito fauna (Diptera: Culicidae) of Belarus, Parazitologiya, 2019, vol. 53, no. 5, p. 399.

https://doi.org/10.1134/S0031184719050041

Taldrik, A.A., Bloodsucking Diptera in the eastern districts of Leningrad Province and protection of livestock using Betimin and Karboksil, Extended Abstract of Candidate's Dissertation in Veterinary Medicine, Leningrad, 1967.

Tamarina, N.A. and Aleksandrova, K.V., On mosquitoes (Diptera: Culicidae) of the White Sea coast. I. Species review, Nauchn. Dokl. Vyssh. Shk. Biol. Nauki, 1974, vol. 8, p. 16.
Utrio, P., A checklist of Finnish mosquitoes (Diptera, Culicidae), including Aedes annulipes, new to Finland, Not. Entomol., 1977, vol. 57, p. 130.

Wilkerson, R.C., Linton, Y.-M., Fonseca, D.M., Schultz, T.R., Price, D.C., and Strickman, D.A., Making mosquito taxonomy useful: a stable classification of tribe Aedini that balances utility with current knowledge of evolutionary relationships, PLoS One, 2015, vol. 10, no. 7: e0133602. https://doi.org/10.1371/journal.pone.0133602

Yasyukevich, V.V., Popov, I.O., Popova, E.N., and Yasyukevich, N.V., Using the "sum of active temperatures" and "sum of effective temperatures" climate indices to estimate the distribution of human pathogens, in Tezisy dokladov Vserossiiskoi nauchnoi konferentsii "Monitoring sostoyaniya i zagryazneniya okruzhayushchei sredy. Osnovnye rezul taty i puti razvitiya," Moskva, 20-22 marta 2017 g. (Abstracts of Papers of the All-Russian Conf. "Monitoring of the Environment State and Pollution: the Main Results and Development, Moscow, March 20-22, 2017), Moscow, 2017, p. 196.

Yasyukevich, V.V., Popov, I.O., and Yasyukevich, N.V., Simulation of changes in the nosoarea and epidemic risk zone of West Nile encephalitis in the territory of Russia as related to the expected climate changes, Probl. Ekol. Monit. Model. Ekosist., 2019, vol. 30, no. 3, p. 28. 